\title{
Nanoparticle-mediated synergistic chemoimmunotherapy for tailoring cancer therapy: recent advances and perspectives
}

\author{
Rafieh Bagherifar ${ }^{1,2}$, Seyed Hossein Kiaie ${ }^{1,3}$, Zahra Hatami ${ }^{4}$, Armin Ahmadi ${ }^{5}$, Abdolvahid Sadeghnejad ${ }^{6}$, \\ Behzad Baradaran ${ }^{7}$, Reza Jafari ${ }^{8,9^{*}}$ and Yousef Javadzadeh ${ }^{10^{*}}$
}

\begin{abstract}
Nowadays, a potent challenge in cancer treatment is considered the lack of efficacious strategy, which has not been able to significantly reduce mortality. Chemoimmunotherapy (CIT) as a promising approach in both for the first-line and relapsed therapy demonstrated particular benefit from two key gating strategies, including chemotherapy and immunotherapy to cancer therapy; therefore, the discernment of their participation and role of potential synergies in CIT approach is determinant. In this study, in addition to balancing the pros and cons of CIT with the challenges of each of two main strategies, the recent advances in the cancer CIT have been discussed. Additionally, immunotherapeutic strategies and the immunomodulation effect induced by chemotherapy, which boosts CIT have been brought up. Finally, harnessing and development of the nanoparticles, which mediated CIT have expatiated in detail.
\end{abstract}

Keywords: Chemoimmunotherapy, Chemotherapy, Immunotherapy, Nanoparticles, Monoclonal antibody, Cytokines

\section{Introduction}

Despite advances in promoting knowledge about cancer initiation and progress, utilization of primary, adjuvant, and palliative treatment approaches, and the development of innovative therapies, overall cancer patient survival rates have slightly improved. Cancer treatments based on palliative treatment approaches alone, such as chemotherapy, immunotherapy, and radiotherapy could not display considerable efficacy [1-3]. Therefore, the expansion of new strategies to control survival and death in cancer therapy is necessary [4-6]. Over the past decades, chemotherapy used drugs with anti-cancer activity that inhibit proliferation of cancer cells, divided in

\footnotetext{
*Correspondence: Jafari.reza@umsu.ac.ir; javadzadehy@yahoo.com

${ }^{8}$ Solid Tumor Research Center, Cellular and Molecular Medicine Institute,

Urmia University of Medical Sciences, Shafa St, Ershad Blvd., P.O. BoX:

1138, 57147 Urmia, Iran

${ }^{10}$ Biotechnology Research Center, and Faculty of Pharmacy, Tabriz University of Medical Science, 5166-15731 Tabriz, Iran

Full list of author information is available at the end of the article
}

an uncontrolled manner. The struggle to discover effective chemotherapeutic drugs came back to the beginning of the twentieth century. For the first time in 1948, chemodrug agents improved acute lymphoblastic leukemia (ALL) in children. In the 1950s, Eli Lilly and Company presented the benefit of plant alkaloids (from Vinca rosea) for ALL patients, and in 1957, 5-fluorouracil was discovered with broad-range activity against many solid tumors $[7,8]$. Chemotherapy, depending on the cancer type, has been used to prevent cancer relapse, inhibit metastasis, accelerate the tumor shrinkage, and reduce the tumor pressure effect. The most common action mechanisms include alkylating agents, antimetabolites, mitotic spindle inhibitors, and topoisomerase inhibitors $[9,10]$. Chemotherapy not only impacts tumor cells but also overwhelms healthy cells; therefore, these adverse effects could also affect normal cell functions. According to the unspecified distribution and multidrug resistance (MDR) of chemotherapeutic drugs, it could cause some disadvantages such as rapid clearance and poor 
pharmacokinetics (PK), as well as numerous adverse effects $[11,12]$. The adverse effects of chemotherapy might be determined by different factors such as drug (type and dose) and cancer ( class and location), as well as the general health status of patients [13, 14]. Likewise, the most common adverse effects of chemotherapy include opportunistic infectious diseases, fatigue, hair loss, diarrhea, nausea and vomiting, anemia, easy bruising and bleeding, and pain such as headaches and stomach and muscle pains [15].

Lately, cancer immunotherapy, which improves the anti-tumor immune responses through stimulation or suppression of the immune system components and activity, displays encouraging results in cancer treatment $[16,17]$. Immunotherapy currently has been a tremendous interest in developing a broad spectrum of cancer therapy from the cold tumor, such as cervical and pancreatic cancers to the hot tumor, such as lung cancer and melanoma $[18,19]$.

The first scientific attempt at modulating the function of the immune system to treat cancer by Fehleisen and Busch was occurred in 1974 [20]. William B. Coley announced the second significant effort to utilize the immune system to treat bone cancer in 1891 [21, 22]. Coley's principles were established and planned under a clinical trial by Old et al. in 1959 [23]. During this same decade, the concept of immunosurveillance was established by Thomas [24] and Burnet $[25,26]$. In comparison to traditional therapies, immunotherapy by using the immune system to fight tumor cells and due to selectivity and long-lasting effects, demonstrates overall survival benefit in preclinical studies and less toxicity on healthy cells leading to the reduction of the adverse effects which followed by traditional therapies $[27,28]$. However, cancer cells evade the immune system by creating a suppressive microenvironment using various strategies such as expressing inhibitory molecules or recruiting cells to secrete suppressive compounds, leading to a decrease in the effectiveness of immunotherapeutic approaches. Therefore, modulation of the immune-suppressive tumor microenvironment (TME) is a pivotal player in cancer immunotherapy, which inhibits the immune system's suppressive factors and promotes the function of the components of the immune system [29-32]. In contrast, the most common obstacles in cancer immunotherapy include unpredictable efficacy due to variability in target mutations, unknown cancer biomarkers and pathways, tumor heterogeneity, immunosuppression and biomarker identification such as technical limitation for recognition of predictive genetic mutations, and cost $[6,33]$. Despite successful cancer treatment achievements by using immunotherapy or chemotherapy alone, the limitations hindered the harnessing, development, and administration of each of the immunotherapy or chemotherapy approaches alone in cancer therapy.

Chemoimmunotherapy (CIT) is able to combine and use both traditional chemotherapy and current immunotherapy approaches to inhibit tumor progression, metastasis and recurrence even if it is not possible to obtain a cure or relieve the symptom in palliative care $[34,35]$. Chemotherapy drug firstly kills the tumor cells and generates cross-presented tumor antigens, making the tumor as a source of tumor antigens. Afterwards, the simultaneous or sequential administration of immunotherapeutic agents leads to stimulation of the tumor antigens and immunostimulants to create a potent anti-tumor immune response [36]. Moreover, immunotherapy could overcome the limitations arising from low specificity and high drug resistance of chemotherapy agents while enhancing sensibility of tumor cells to chemotherapy agents $[37,38]$. Therefore, this combination system could increase therapeutic effectiveness through synergistic effects. Moreover, it has been demonstrated that some chemotherapy drugs alone induce immunomodulation effects through immunogenic cell death (ICD), sensitizing tumor cells to immune assault, and elimination of immunosuppressive cells in the TME. These drugs show the potential for CIT as single agent or in combination with other chemotherapy or immunotherapy drugs [39-41]. CIT has been used in pre-clinical studies or even in clinical trials and in different types of cancers, especially melanoma, breast cancer, hepatic tumor, prostate cancer, and lung cancer [42]. A study analysis of Food and Drug Administration (FDA)-approved products for chemotherapy, immunotherapy and CIT approaches highlighted harnessing and development of CIT for the prospects of more clinical use in cancer treatment. A pivotal events timeline for FDA-approved chemotherapy, immunotherapy, and CIT products with year from 2015 to 2020 are pointed out in Fig. 1. This review aims to discuss a compelling role of CIT as potential synergies of tailored cancer, which begins with a discussion of immunotherapeutic strategies and chemotherapy with immunogenic effect which boost CIT and interplay of chemotherapy and overlap between innate and adaptive immunity. Then, potential of nanoparticles (NPs)-assisted CIT illustrates the promising way in which prospect of the CIT researches will be considered. To that end, carriermediated CIT with the combination of chemotherapy drugs and immunotherapeutic agents, including cytokines, immune adjuvants, monoclonal antibodies (mAbs), and other immunotherapy agents for synergistic cancer therapy is explored in detail. 


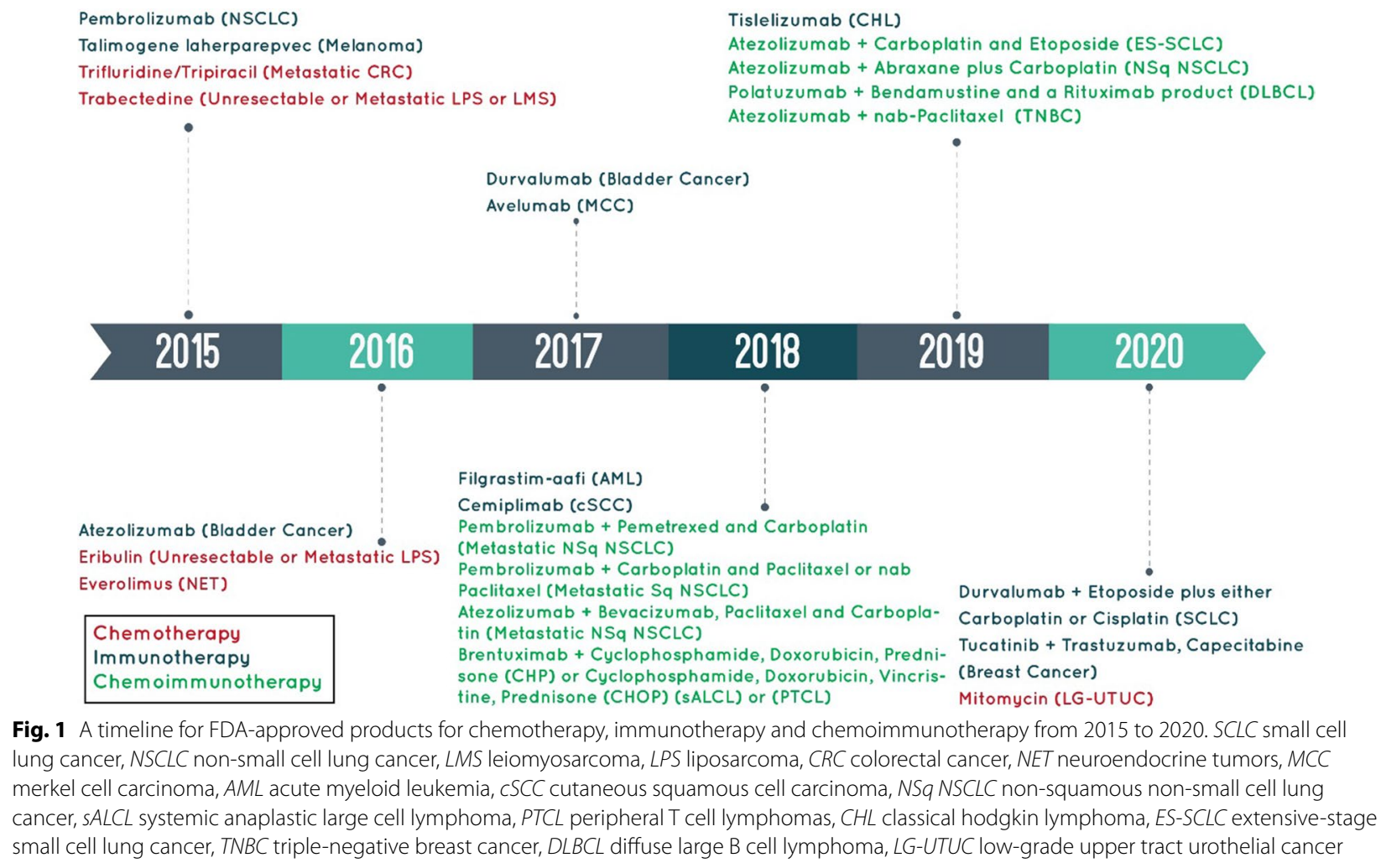

Filgrastim-aafi (AML)

Cemiplimab (cSCC)

2017

Atezolizumab (Bladder Cancer) : (Metastatic NSq NSCLC)

Eribulin (Unresectable or Metastatic LPS) Everolimus (NET)

Pembrolizumab + Carboplatin and Paclitaxel or nab Paclitaxel (Metastatic Sq NSCLC)

Atezolizumab + Bevacizumab, Paclitaxel and Carboplatin (Metastatic NSq NSCLC)

Brentuximab + Cyclophosphamide, Doxorubicin, Prednisone (CHP) or Cyclophosphamide, Doxorubicin, Vincris-

tine, Prednisone (CHOP) (sALCL) or (PTCL)

Atezolizumab + Carboplatin and Etoposide (ES-SCLC)

Atezolizumab + Abraxane plus Carboplatin (NSq NSCLC)

Polatuzumab + Bendamustine and a Rituximab product (DLBCL)

Atezolizumab + nab-Paclitaxel (TNBC)

Fig. 1 A timeline for FDA-approved products for chemotherapy, immunotherapy and chemoimmunotherapy from 2015 to 2020. SCLC small cell lung cancer, NSCLC non-small cell lung cancer, LMS leiomyosarcoma, LPS liposarcoma, CRC colorectal cancer, NET neuroendocrine tumors, MCC merkel cell carcinoma, AML acute myeloid leukemia, CSCC cutaneous squamous cell carcinoma, NSq NSCLC non-squamous non-small cell lung cancer, SALCL systemic anaplastic large cell lymphoma, PTCL peripheral T cell lymphomas, CHL classical hodgkin lymphoma, ES-SCLC extensive-stage small cell lung cancer, TNBC triple-negative breast cancer, DLBCL diffuse large B cell lymphoma, LG-UTUC low-grade upper tract urothelial cancer

\section{Immunotherapeutic strategies to boost chemoimmunotherapy}

Immunotherapy is classified into two types, active and passive, based on the patients' immune system status and the mechanism of immunotherapeutic agents. Passive immunotherapy, which utilizes immunotherapeutic agents like cytokines, tumor-specific mAbs, adoptive cell transfer therapy (ACT), and immune adjuvants optimizes the host's immune system to fight tumor cells efficiently, rather than inducing cancer cell death. In comparison to active immunotherapy, which creates long-lasting immunity, passive immunotherapy requires repeated administration $[43,44]$. mAbs are proteins that engineered to bind to tumor-specific antigens and can be used alone or conjugated to specific medications, toxins, or radioactive agents and carry them to cancer cells [45]. ACT, also known as cellular immunotherapy, is the most effective immunotherapeutic approach, which involves isolating a cancer patient's tumor-specific lymphocytes, ex vivo modification, activation and expansion, and subsequently, their reinfusion to the patient [46]. Three forms of ACT, including tumor-infiltrating T lymphocyte (TIL), chimeric antigen receptor (CAR) $\mathrm{T}$ cell, and engineered $\mathrm{T}$ cell receptor (TCR), have been developed for cancer therapy [47]. In CAR T cell- and TCR therapy, patientderived $\mathrm{T}$ lymphocytes are engineered ex vivo to express artificial $\mathrm{T}$ cell receptors or equipped with synthetic $\mathrm{T}$ cell receptors, respectively. As a result, $\mathrm{T}$ lymphocytes gain the ability to target cancer cells $[48,49]$. Unlike TIL and TCR, CARs can bind to tumor cells in an MHCindependent fashion [50]. Cytokines are a broad class of small soluble proteins secreted by certain cells like macrophages (MQs), T cells, B cells, and mast cells. They act as a mediator of cell communication, cause immune cells growth and differentiation, and regulate inflammatory or anti-inflammatory responses in various cell types [51]. Pro-inflammatory cytokines (PICs) in the initial steps of tumorigenesis display anti-tumor activity by improving antigen priming, stimulating immune effector cells, and increasing the number and cytotoxic activity of immune cells in the TME [52, 53]. As such, some cytokines can kill tumor cells either directly through providing anti-proliferative and pro-apoptotic tumor signals or indirectly by activating cytotoxic immune cells. Moreover, cytokines in combination with mAbs, which inhibit immune checkpoint (ICP) molecules such as programmed cell death ligand-1 (PD-L1) and programmed cell death protein-1 (PD-1), have been used in several clinical trials [54]. On the other hand, some cytokines like interleukin (IL)-10 and transforming growth factor- $\beta$ (TGF- $\beta$ ), which are released from cancer cells and the TME cells, could promote tumorigenesis and suppress the immune system. 
In this case, different strategies including antagonistic antibodies, polypeptides, cytokine traps, and small molecules that inhibit cytokine receptor signal transduction are used to neutralize the immunosuppressive activity of cytokines [52]. To date, interferon- $\alpha$ (IFN- $\alpha$ ) and IL-2 have received FDA approval for the treatment of several cancers as monotherapy $[55,56]$. Adjuvant is a molecule that potentiates the innate immune responses through activation of pathogen recognition receptors (PRRs) like NOD-like receptors (NLRs) as well as toll like receptors (TLRs) by their agonists. Subsequently, this activation leads to the production of cytokine and chemokine, which in turn promote the activation and maturation of antigen-presenting cells (APCs) [57]. Lipopolysaccharide (LPS), cytosine-phosphate-guanosine oligodeoxynucleotides (CpG-ODN), agonists of stimulator of interferon genes (STING), and polyinosinic-polycytidylic acid (poly $\mathrm{I}: \mathrm{C})$ are commonly used adjuvants in cancer immunotherapy [58]. Thus, adjuvants have attracted more attention as a crucial component of cancer vaccines. Combining the adjuvants with tumor-specific antigens in different types of effective cancer vaccines has been developed in cancer immunotherapy. To that end, these adjuvant vaccines have been internalized into APCs using NPs that could enhance immunity against cancer [59].

On the other hand, active immunotherapy approaches cause in vivo activation of host's immune system through stimulation of effector cells functions and induce cancer cell death through immune checkpoint inhibitors (ICIs), oncolytic viruses, and different types of anti-cancer vaccines such as peptide vaccines, wholecell vaccines, and dendritic cell (DC)-based vaccines [60]. Moreover, the TME is usually immunosuppressive in various cancers. Thus, tumor immunotherapy's primary strategy is to disrupt immunosuppressed microenvironment while inducing an effective $\mathrm{T}$ cell response against tumor epitopes and providing a stable immunological memory against a wide repertoire of cancer epitopes [61]. Cancer cells do not express danger signals at the early stage, so the immune system cannot respond to tumor antigens. The DC vaccine stimulates anti-tumor immune responses in cancer patients to correct this failure by producing efficient antigen-specific $\mathrm{T}$ cells. The combination of DC vaccine with other immunotherapy agents is used in several clinical studies. For instance, the combination of DC vaccine with mAbs (anti-programmed cell death protein-1 (PD-1) and anti-CTLA-4), or other ICIs has been studied [62]. In another study, blockade of programmed cell death ligand-1 (PD-L1) expression on DCs, which enhanced $\mathrm{T}$ cell priming potential of $\mathrm{DC}$ vaccine has been indicated [63, 64]. Immune checkpoint (ICP) molecules, including CTLA-4 and PD-1/ PD-L1 impede T cells' anti-tumor activity through the transmission of inhibitory signals leading to downregulation in immune responses [65, 66]. ICIs are mAbs that target ICP molecules and activate anti-tumor immunity with different types of malignancies such as prostate and pancreatic cancers, metastatic melanoma, renal cell carcinoma (RCC) and non-small cell lung cancer (NSCLC) [67-71]. Due to the high expression of PD-L1 in most tumor cells, cytokine secretion and $\mathrm{T}$ cell proliferation and function are significantly inhibited by the unique PD-1 expressed on the $\mathrm{T}$ cell surface, which eventually leads to immunosuppression [72]. ICP blockade has yielded success in the clinic, and seven ICIs have been received FDA approval since 2011 [66, 73].

\section{Induction of immunomodulation by chemotherapy}

Chemotherapy has been partially successful in treating many types of cancers. Some chemotherapeutic agents kill the tumor cells not only by inducing non-immunogenic apoptosis and cytotoxic effect but also by creating immunological changes and stimulating the host's immune responses [74]. Several mechanisms involved in immune activation induced by chemotherapy comprise ICD induction, elimination of immunosuppressive cells in the TME, and sensitizing tumor cells to immune attack [75].

\section{Immunogenic cell death}

Killing tumor cells by chemotherapy through induction of ICD or immunogenic apoptosis results in the secretion of damage-associated molecular patterns (DAMPs), like calreticulin (CRT), high mobility group box 1 (HMGB1) and adenosine triphosphate (ATP). Exposure of CRT on dying tumor cell surface leads to antigen engulfment and stimulation of uptake and presentation of tumor-specific antigens by DCs, which in turn causes activation of CTLs to kill tumor cells [76-78]. HMGB1 also induces antigenspecific $\mathrm{T}$ cell-mediated immune response by promoting DCs to attach to dying cancer cells [79]. ATP's release facilitates the recruitment and differentiation of $\mathrm{T}$ cells and DCs through the autophagy pathway [80]. Some chemotherapeutic agents such as oxaliplatin, idarubicin, epirubicin, cyclophosphamide (CP), and doxorubicin (DOX) can induce ICD [81].

\section{Elimination of immunosuppressive cells in the TME}

Some immunosuppressive cells such as M2-type tumorassociated macrophages (TAMs), regulatory $\mathrm{T}$ cells $\left(\mathrm{T}_{\text {reg }} \mathrm{s}\right)$, and myeloid-derived suppressor cells (MDSCs), which are found in the TME, suppress anti-cancer activity of immune cells. Anti-inflammatory IL-10 and TGF- $\beta$ released by $\mathrm{T}_{\text {reg }} \mathrm{s}$ and TAMs directly suppress $\mathrm{T}$ cells' cytotoxic activity and inhibit co-stimulatory ligand expression on DCs, which induces anergy. Moreover, 
MDSCs inhibit T and NK cells' proliferation and activity by expanding $\mathrm{T}_{\text {reg }} \mathrm{s}$ and proliferation to M2-type MQs [82-84]. Chemotherapeutic agents such as cisplatin (CDDP) plus paclitaxel (PTX) directly augment the TME by eliminating these immunosuppressive cells and antiinflammatory cytokines [85].

\section{Sensitization of tumor cells to immune attack}

CTLs release perforin and granzyme B (Grz B) after interaction with tumor cells. Chemotherapeutic agents can enhance the permeability of tumor cell membrane to Grz B, which leads to enhanced uptake of Grz B and sensitization of tumor cells to CTLs [86].

\section{Chemotherapy and the overlap between innate and adaptive immunity}

The immune system is divided into two components comprising innate and adaptive immunity, which indicate key roles in creating non-specific and antigen-specific immune responses against cancer, respectively [87]. Moreover, there is an essential interface between these two components, such as natural killer T (NKT) cells and gamma-delta $(\gamma \delta) \mathrm{T}$ cells that are promising candidates for cancer immunotherapy owing to the modulation ability of both innate and adaptive immunity [88]. The representational overlap between innate and adaptive immunity was illustrated in Fig. 2. $\gamma \delta \mathrm{T}$ cells recognize different types of tumor cells in an MHC-independent manner and produce PICs such as IFN- $\gamma$. Two strategies, comprising adoptive transfer of $\gamma \delta \mathrm{T}$ cells to patient following ex vivo expansion of them, and in vivo stimulation of $\gamma \delta \mathrm{T}$ cells using systemic administration of synthetic phosphoantigens (pAgs) or amino-bisphosphonates (N-bis) (pamidronate or zoledronate) have been applied in $\gamma \delta \mathrm{T}$ cell-based cancer immunotherapy [89, 90]. NKT cells, a subset of CD1d-restricted T cells, have also been proved as a promising boon in manifestation of cancer immunotherapy through a variety of mechanisms, including killing tumor cells directly, influencing immunosuppressive cells in the TME, secretion of cytokines, and stimulating tumor-specific $\mathrm{T}$ cells and NK cells which leads to elimination of tumor cells [91, 92].

A combination of $\gamma \delta \mathrm{T}$ cell- and NKT cell-based therapies with chemotherapy leads to significant cancer treatment efficiency due to their potent anti-tumor cytotoxicity. In fact, these immune cells recognize and kill tumor cells using various mechanisms, and most probably, chemotherapy will enhance their cytotoxicity through one of these pathways [93]. Co-encapsulation of alendronate, a bisphosphonate which activates $\gamma \delta$ T cells and DOX, a chemotherapeutic agent in a pegylated liposome, leads to a synergistic anti-tumor effect in breast tumor models [94]. In another study, a high synergistic effect and the highest apoptosis level were achieved when breast cancer cell lines were treated with PTX followed by zoledronic acid compared to reverse sequence or simultaneous treatment. Before immune cell therapy, administration of chemotherapeutic agents could sensitize tumor cells to immunotherapy, while posing no risk of immune cell suppression, which is usually occurred in



Innate immunity

Adaptive immunity

Fig. 2 The representational overlap between innate and adaptive immunity 
simultaneous administration. As a result, such combination therapies' synergistic effects appear to be sequentialdependent $[95,96]$.

\section{Balancing the pros and cons of chemoimmunotherapy}

CIT as the miracle cure is now being utilized through many approved therapies for major cancer types, including lung cancer, breast cancer, and lymphoma and being improved and hoped in endpoints for the phase (III and V) of clinical trials for colon cancer stage III, CRC [96, 97] and pancreatic cancer [98]. Although chemotherapy has been passed the long way as a standard treatment for cancer, however, may not be effective enough as monotherapy in the palliative treatment of patients with cancer due to dose-dependent cytotoxicity. Lowdose chemotherapeutic agents often are ineffective and cause recurrence and metastasis of tumor cells while the administration of high doses leads to severe side effects and immunosuppression; therefore, systemic toxicity will subsequently appear. Moreover, tumor cells have evolved various mechanisms to escape from the immune system because the TME usually plays an immunosuppressive role in multiple types of cancers [99]. Hence, immunotherapeutic approaches will be useful in cancer treatment. Nonetheless, immunotherapy as monotherapy also is not sufficient to overcome tumor cells, due to the attendance of immune system inhibitor cells in the suppressive TME and lack of cytotoxic cells penetration into the tumor. Considering the limitations of chemotherapy and immunotherapy, preclinical and clinical studies aim to enhance the anti-cancer efficacy by combining monotherapies $[100,101]$. Treatment with chemotherapy creates necrotic and apoptotic cells in tumor tissue. These materials contain antigens and CTL epitopes which can be released into lymphatic or blood vessels or incorporate into APCs like DCs. In the following, APCs present the derived epitopes and antigens to CTL precursors. As a result, chemotherapy treatment creates an antigen specific immune response and CIT achieves the improvement in the results of both immunotherapy and chemotherapy. In fact, when chemotherapy is combined with immunotherapy, low concentrations of chemotherapeutic drugs is expected to have maximum effect on tumor cells and minimum side effect on normal cells $[102,103]$.

In general, cancer immunotherapies work through immunomodulating the characteristics of the TME, stimulating the function of $\mathrm{T}$ cells, eliminating immunosuppressive immune cells, and finally augmenting endogenous immunity to inhibit tumor growth [17].

One of the promising cancer immunotherapy strategies is the utilization of immunomodulators. The immunomodulation is based on stimulating the function of $\mathrm{T}$ cells by blocking or activating regulatory receptors using antibodies, which prevents the progression of cancer. Recently, antibody-based immunotherapy has shifted to targeting immune cells instead of cancer cells. The most critical immunomodulatory antibodies are ICIs that target the PD- 1 and CTLA-4 inhibitory receptors on the surface of $\mathrm{T}$ cells and, by binding to them, activate antitumor $\mathrm{T}$ cells to destroy tumor cells $[104,105]$. Immunomodulation effects of ICIs may be complemented by the immunogenic effects of chemotherapeutic agents such as increasing mutation burden and neoantigen load, enhancement of T-cell priming and recruitment to the tumor, and increasing MHC I expression to promote antigen presentation [106]. Several randomized clinical trials demonstrated that combining ICIs with chemotherapy may improve their anti-tumor activity in different types of tumors, especially NSCLC $[107,108]$. One research group showed that the addition of chemotherapy to PD-1 blockade resulted in improved clinical response in patients with metastatic melanoma [109].

Another modality of cancer immunotherapy is targeting immunosuppressive elements such as MDSCs and $\mathrm{T}_{\text {regs }}$ in the TME, which demonstrates an essential role in cancer progression and metastasis through inhibition of proliferation and activation of killer $\mathrm{T}$ cells. Several immunotherapy approaches are applied to eliminate MDSCs and $\mathrm{T}_{\text {regs }}$ or impair their immunosuppressive function in different malignancies [110]. Moreover, beyond their direct cytotoxic effects on tumor cells, chemotherapeutic drugs like immunotherapeutic agents can eliminate or inactivate MDSCs and $\mathrm{T}_{\text {regs }}$ through several mechanisms. Likewise, it has been shown that $\mathrm{CP}$ reduces the number of $\mathrm{T}_{\text {regs }}$ via induction of apoptosis in a mouse model, without affecting $\mathrm{T}$ effector viability, which can be attributed to higher proliferation rate of $\mathrm{T}_{\text {regs }}$ compared to other cells [111]. Furthermore, PTX was reported to reduce the number of MDSCs by inducing differentiation of MDSCs into non-immunosuppressive cell types, DCs [112]. Therefore, the combination of these chemotherapeutic agents with immunotherapy approaches that target MDSCs or $\mathrm{T}_{\text {regs }}$ appears to be effective in cancer treatment. For instance, the combination of $\mathrm{CP}$ and immunotherapy resulted in improved overall survival in colon cancer models [113]. Moreover, it has been reported that inhibition of exosome formation using amiloride blunts the immunosuppressive activity of MDSCs and enhances the anti-tumor efficacy of CP in different mouse tumor models [114].

Immune activation at the forefront of cancer immunotherapy plays a role via several immune stimulants such as cytokines and agonists. Cytokines have several functions, including induction of DC maturation, proliferation and activation of $\mathrm{T}$ and $\mathrm{NK}$ cells, and enhancement 
of MHC expression on MQs and DCs [115]. Similarly, some chemotherapy drugs, including $\mathrm{CP}$, have been shown to promote DC maturation [116]. DOX and oxaliplatin also induce $\mathrm{T}$ cell stimulation through facilitating tumor antigen uptake by DCs. Due to cytokines and chemotherapy drugs' common effects on immune activation, their combination leads to a synergistic effect in various cancers $[117,118]$.

The full gating functional pathway of chemotherapy and immunotherapy and CIT strategies in tumor-fighting with supporting players in the TME was described in Fig. 3.

\section{Nanoparticle-mediated chemoimmunotherapy}

Despite the promising benefits of CIT in cancer treatment, there are still critical challenges, including the obstacles in the simultaneous delivery of therapeutic agents to target tissues and cells. Chemotherapeutic drugs and immunotherapeutic agents usually have different physicochemical properties and mechanisms and may affect different targets in vivo. They also have distinct $\mathrm{PK}$ and in vivo distribution, which results in unpredictable drug ratios at tumor tissues. Furthermore, the unstable structure of most immunotherapeutic agents against enzymatic degradation and chemical conditions leads to the loss of their biological activity [119]. Hence, it is essential to develop a carrier which can load and deliver these two agents simultaneously and achieve synergistic and efficient combination therapy [120].

The manifestation of nanosized carriers has facilitated the rational integration of these distinct approaches and increased the efficacy of CIT to achieve a potential anti-cancer treatment. Harnessing of NPs decreases offtarget side effects by increasing therapeutic agents' exposure to target cells and increases the stability of drugs by protecting them from degradation. Moreover, nanobased co-delivery systems could ascertain the targeted delivery and controlled release of drugs, remodel the

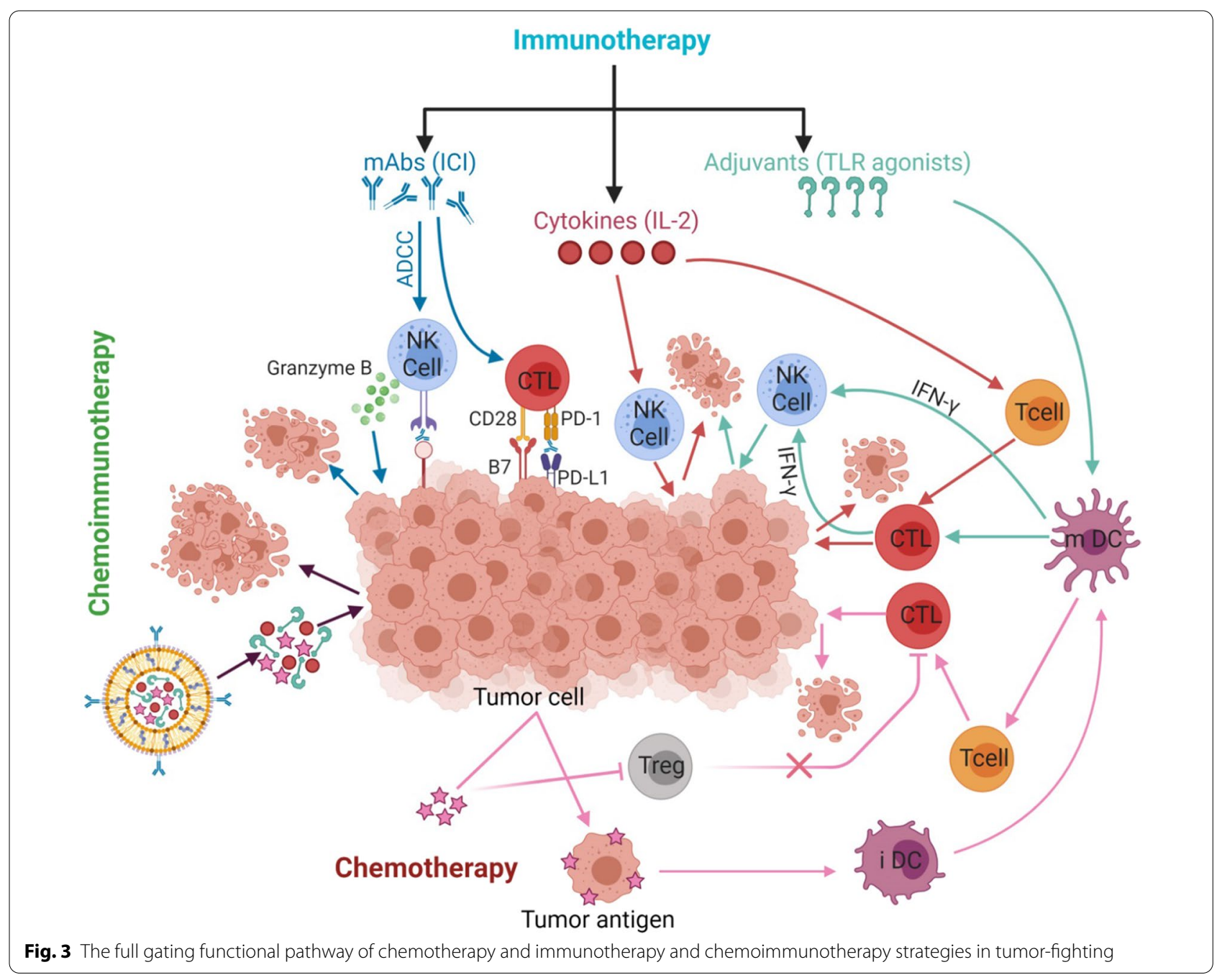


Table 1 Carrier-mediated combination of chemotherapy drugs and cytokines

\begin{tabular}{|c|c|c|c|c|c|}
\hline $\begin{array}{l}\text { Carrier design (Structure/Injection } \\
\text { route) }\end{array}$ & $\begin{array}{l}\text { Chemotherapy } \\
\text { agent }\end{array}$ & Cytokines & Tumor type & $\begin{array}{l}\text { Synergic actions and advantages of NPs in the } \\
\text { combination }\end{array}$ & Refs. \\
\hline Polymeric NPs (TMC/SC) & DOX & rhlL-2 & Hepatic tumor & $\begin{array}{l}\text { Protection of rhIL-2 from enzymolysis without any } \\
\text { damage on its bioactivity } \\
\text { Considerable inhibition of tumor growth and } \\
\text { enhancement of IgG and CTLs levels compared } \\
\text { with free drug }\end{array}$ & [142] \\
\hline Hybrid NPs (Lipid coated MSNs/IV) & & ATRA $+I L-2$ & Melanoma & $\begin{array}{l}\text { Enhancement of anti-tumor efficacy and consider- } \\
\text { able delay in tumor growth and metastasis } \\
\text { Activation of TILs and NK cells } \\
\text { Induction of IL-12 and IFN- } \gamma \text { secretion and downregu- } \\
\text { lation of MDSCs, IL-10, and TGF- } \beta\end{array}$ & [120] \\
\hline $\begin{array}{l}\text { Polymeric NPs (PLGA as core and } \\
\text { PEO-PPO-PEO as shell/IV) }\end{array}$ & & IFN- $\gamma$ & & $\begin{array}{l}\text { Excellent synergistic anti-tumor efficiency } \\
\text { Activation of CD4 } 4^{+} T \text { cells, CTLs, and NK cells } \\
\text { Induction of IL-2 and TNF-a secretion and downregu- } \\
\text { lation of expression of IL-10 and TGF- } \beta\end{array}$ & [143] \\
\hline Hydrogel NPs (PELG-PEG-PELG) & & $\mathrm{IL}-2+\mathrm{IFN}-\gamma$ & & $\begin{array}{l}\text { Increased anti-tumor efficacy toward free drugs due } \\
\text { to sustained release of drugs } \\
\text { Increased proliferation of } \mathrm{CD}^{+} / \mathrm{CD}^{+} \text {and } \mathrm{CD}^{+} / \\
\text {CD4 }{ }^{+} T \text { cells }\end{array}$ & [144] \\
\hline $\begin{array}{l}\text { Cell-derived nanovesicles (DC 2.4/ } \\
\text { IV) }\end{array}$ & & $\mid \mathrm{L}-2, \mathrm{IL}-2+\mathrm{IFN}-\gamma$ & $\begin{array}{l}\text { Melanoma and } \\
\text { breast cancer }\end{array}$ & $\begin{array}{l}\text { Efficient inhibition of primary } 4 \mathrm{TT} 1 \text { tumor progression } \\
\text { and lung metastasis of breast cancer } \\
\text { Enhancement of DC maturation, promotion of infil- } \\
\text { tration and activation of CD8 }{ }^{+} \text {cells and NK cells } \\
\text { Increase in recruitment of } \mathrm{Ly}^{+} \mathrm{G}^{+} \text {neutrophils and } \\
\text { CD45 } 45^{+} \text {immune cells }\end{array}$ & [145] \\
\hline $\begin{array}{l}\text { Nanogels (PPLG and HPCS/PPLL/ } \\
\text { SC) }\end{array}$ & & rhlL-2 +rhIFN- $\gamma$ & $\begin{array}{l}\text { NSCLC and } \\
\text { breast cancer }\end{array}$ & $\begin{array}{l}\text { Prolonged and continuous release of payloads } \\
\text { Significant inhibition of tumor cell proliferation } \\
\text { Synergistic anti-cancer efficacy via regulation of } \\
\text { apoptosis-related genes in xenograft tumor- } \\
\text { bearing mice }\end{array}$ & [146] \\
\hline $\begin{array}{l}\text { Polymeric NPs (PLGA-mPEG-PLGA) } \\
\text { IV) }\end{array}$ & PTX & IL-2 & Melanoma & $\begin{array}{l}\text { Remarkable inhibition of tumor growth and metas- } \\
\text { tasis } \\
\text { Prolonged overall survival of treated mice in compari- } \\
\text { son to chemotherapy or cytokine therapy alone } \\
\text { Promotion of tumor immunogenicity and the anti- } \\
\text { tumor response of immune cells }\end{array}$ & [147] \\
\hline $\begin{array}{l}\text { Nanogels (Erythrocyte membrane } \\
\text { coated nanogels/IV) }\end{array}$ & & & $\begin{array}{l}\text { Metastatic mela- } \\
\text { noma (lung } \\
\text { metastasis) }\end{array}$ & $\begin{array}{l}\text { Extended in vivo circulation time } \\
\text { Increase in anti-tumor activity and improvement in } \\
\text { lung metastasis inhibition of PTX/IL-2 loaded nano- } \\
\text { gel compared to PTX or IL-2 loaded nanogel alone } \\
\text { Decrease in number of immune-suppressive cells and } \\
\text { enhancement of immune effector cells in the TME }\end{array}$ & [148] \\
\hline $\begin{array}{l}\text { Polymeric NPs (mPEG-PDLLA as } \\
\text { core and pluronic F127 as shell/ } \\
\text { IV) }\end{array}$ & & $\mathrm{IL}-12$ & Breast cancer & $\begin{array}{l}\text { Significant accumulation of NPs in tumor cells } \\
\text { because of their acid-sensitive property } \\
\text { Activation of immune effector cells like T cells and } \\
\text { NK cells } \\
\text { Modulation of the immunosuppressive TME by } \\
\text { inhibiting T } T_{\text {regs }} \text { and inducing differentiation of } \\
\text { M1-type MQs } \\
\text { Prolonged survival of tumor-bearing mice }\end{array}$ & \\
\hline $\begin{array}{l}\text { Polymeric hydrogels (mPEG-b- } \\
\text { PELG-based hydrogels/SC) }\end{array}$ & CDDP & IL-15 & Melanoma & $\begin{array}{l}\text { Inducing cell cycle arrest, synergistic anti-cancer } \\
\text { efficacy, and reduced systemic toxicity compared } \\
\text { to monotherapy } \\
\text { Enhanced anti-tumor immunity owing to suppres- } \\
\text { sion of } \text { T }_{\text {regs }} \text { and activation of NK cells and CTLs }\end{array}$ & \\
\hline
\end{tabular}


Table 2 Carrier-mediated combination of chemotherapy drugs and immune adjuvants

\begin{tabular}{|c|c|c|c|c|c|}
\hline $\begin{array}{l}\text { Carrier design } \\
\text { (Structure/injection } \\
\text { route) }\end{array}$ & $\begin{array}{l}\text { Chemotherapy } \\
\text { agent }\end{array}$ & Immune adjuvants & Tumor type & $\begin{array}{l}\text { Synergic actions and advantages of NPs in the } \\
\text { combination }\end{array}$ & Refs. \\
\hline $\begin{array}{l}\text { Hybrid NPs (G4-Arga / } \\
\text { PLGA-PEG-PLGA } \\
\text { hydrogel/IV) }\end{array}$ & DOX & L-Arg & Breast cancer & $\begin{array}{l}\text { High therapeutic efficacy and great tumor growth } \\
\text { inhibition in } 4 \mathrm{~T} 1 \text { cells-xenografted mice } \\
\text { Synergistic immune therapy through the production } \\
\text { of NO by providing a substrate (L-Arg) of iNOS in MQs }\end{array}$ & [151] \\
\hline \multirow[t]{2}{*}{$\begin{array}{l}\text { Lipid NPs (TH } \\
\text { peptide-modified } \\
\text { liposomes/IV) }\end{array}$} & \multirow[t]{5}{*}{ PTX } & $\begin{array}{l}\text { aGC + PD-L1 (not encap- } \\
\text { sulated in NP) }\end{array}$ & \multirow[t]{2}{*}{$\begin{array}{l}\text { Melanoma and } \\
\text { lung metastasis }\end{array}$} & $\begin{array}{l}\text { Upregulation of IFN- } \gamma \text {, maturation of DCs, and activa- } \\
\text { tion of NKT cells } \\
\text { Significant anti-metastatic effect, enhanced CTL } \\
\text { responses, and prolonged survival }\end{array}$ & [152] \\
\hline & & $\begin{array}{l}\text { aGC + acetyl-CoA } \\
\text { ACAT-1 inhibitor } \\
\text { avasimibe (not encap- } \\
\text { sulated in NP) }\end{array}$ & & $\begin{array}{l}\text { Inhibition of growth and metastasis of melanoma } \\
\text { tumors } \\
\text { Promotion of the anti-tumor effect via stimulation of } \\
\text { CTL responses and formation of TCR } \\
\text { Induction of apoptosis through inhibition of ACAT-1 } \\
\text { due to an increase in free cholesterol level }\end{array}$ & [153] \\
\hline $\begin{array}{l}\text { Polymeric NPs (PLGA/ } \\
\text { Peritumoral) }\end{array}$ & & TLR4 agonist, P-LPS & Melanoma & $\begin{array}{l}\text { Increased anti-tumor immune response at the TME } \\
\text { compared to PTX and P-LPS alone } \\
\text { Activation of APCs and T cells in the tumor site and } \\
\text { induction of Th1 immune response } \\
\text { Enhancement of TNF-a, IFN-Y, and IL-12 secretion } \\
\text { Increase in the infiltration of MQs, DCs, and CD4 }{ }^{+} \text {and } \\
\text { CD8 }{ }^{+} \text {T lymphocytes }\end{array}$ & [154] \\
\hline $\begin{array}{l}\text { Polymeric NPs (PLGA } \\
\text { IV) }\end{array}$ & & TLR4 agonist, SP-LPS & \multirow[t]{2}{*}{$\begin{array}{l}\text { Melanoma and } \\
\text { MQ model }\end{array}$} & $\begin{array}{l}\text { High amount of PTX in tumor mass compared to com- } \\
\text { mercial PTX followed by IV injection } \\
\text { High anti-cancer activity and anti-tumor immune } \\
\text { responses } \\
\text { Activation of MQs and effector immune cells like cyto- } \\
\text { toxic T cells and NK cells in splenocytes } \\
\text { Secretion of various PICs such as IL-12 and TNF-a }\end{array}$ & [155] \\
\hline $\begin{array}{l}\text { Hybrid NPs (Conju- } \\
\text { gate of PTX } \\
\text { and SP-LPS/IV) }\end{array}$ & & TLR4 agonist, SP-LPS & & $\begin{array}{l}\text { Improvement in anti-tumor activity } \\
\text { Enhanced percentage of activated immune cells such } \\
\text { as MQs, especially M1 type and Th cells } \\
\text { Increasing the secretion of IFN- } \gamma \text {, IL-12, and TNF-a }\end{array}$ & [156] \\
\hline $\begin{array}{l}\text { Polymeric NPs (PEG- } \\
\text { PEI/Tail vein) }\end{array}$ & DOX & TLR2 agonist, Zymosan & Breast cancer & $\begin{array}{l}\text { Accumulation of NPs in hypoxic regions of the tumor } \\
\text { Inhibition of tumor progression and metastasis, and } \\
\text { induction of greater apoptosis } \\
\text { Modulation of TAMs differentiation and an increase in } \\
\text { expression of Th1 specific cytokines } \\
\text { Decrease in VEGFR2 expression and facilitation of anti- } \\
\text { angiogenic effect }\end{array}$ & [157] \\
\hline $\begin{array}{l}\text { Hybrid NPs (MS-Zn } \\
\text { micro-rosettes/IV) }\end{array}$ & & Poly I:C sodium salt & $\begin{array}{l}\text { Bilateral LLC cell } \\
\text { inoculation } \\
\text { model }\end{array}$ & $\begin{array}{l}\text { Effective inhibition of tumor growth at the local site } \\
\text { Prevention of distant tumor metastases } \\
\text { Increased IFN- } \gamma \text { secretion and } \mathrm{CD}^{+} \text {and } \mathrm{CD} 8^{+} \mathrm{T} \text { cell } \\
\text { populations }\end{array}$ & [127] \\
\hline $\begin{array}{l}\text { Polymeric NPs (PLGA- } \\
\text { PEG/IV) }\end{array}$ & & $\begin{array}{l}\text { TLR3 agonist, poly } \\
\text { I:C }+ \text { Resiquimod } \\
\text { (R848) immune } \\
\text { adjuvant }+ \text { CCL20 } \\
\text { chemokine }\end{array}$ & $\begin{array}{l}\text { Lung carcinoma } \\
\text { and colon } \\
\text { adenocarci- } \\
\text { noma }\end{array}$ & $\begin{array}{l}\text { Excellent combination therapeutic efficacy compared } \\
\text { to monotherapy } \\
\text { Longer survival rate in treated mice } \\
\text { Strong activation of specific CTLs in the TME and blood } \\
\text { circulation }\end{array}$ & [158] \\
\hline $\begin{array}{l}\text { Hybrid NPs (Aptamer- } \\
\text { G4 PAMAM biocon- } \\
\text { jugate/IV) }\end{array}$ & & TLR9 agonist, CpG ODN & Prostate cancer & $\begin{array}{l}\text { Excellent anti-tumor efficacy and tumor size reduction } \\
\text { in mice treated with combination therapy compared } \\
\text { to free DOX treated group } \\
\text { Higher levels of the IL-1 } 1 \text {, IL-12, IL-6, and TNF-a } \\
\text { cytokines in MQ cells }\end{array}$ & [159] \\
\hline $\begin{array}{l}\text { Biomimetic NPs (HDL } \\
\text { mimicking/IV) }\end{array}$ & & $\begin{array}{l}\text { Aptamer-CpG fused } \\
\text { sequences (Apt-CpG- } \\
\text { DSPE) }\end{array}$ & Lung cancer & $\begin{array}{l}\text { Enhancement of M1 (MQs) switched the immune- } \\
\text { suppressive TME to the immunostimulatory one } \\
\text { Facilitation of cell apoptosis and release of tumor- } \\
\text { associated antigens } \\
\text { Activation of endosomal TLR-9 in infiltrated APCs } \\
\text { Enhancement of secretion of PICs such as IL-6 and } \\
\text { TNF-a }\end{array}$ & [160] \\
\hline
\end{tabular}


Table 2 (continued)

\begin{tabular}{|c|c|c|c|c|c|}
\hline $\begin{array}{l}\text { Carrier design } \\
\text { (Structure/injection } \\
\text { route) }\end{array}$ & $\begin{array}{l}\text { Chemotherapy } \\
\text { agent }\end{array}$ & Immune adjuvants & Tumor type & $\begin{array}{l}\text { Synergic actions and advantages of NPs in the } \\
\text { combination }\end{array}$ & Refs. \\
\hline $\begin{array}{l}\text { Hydrogel NPs } \\
\text { (a-Cyclodextrin- } \\
\text { PEG/Intratumoral) }\end{array}$ & & CpG NP & Melanoma & $\begin{array}{l}\text { Modulation of TME toward immune-suppressive condi- } \\
\text { tion } \\
\text { Enhancement in the number of CTLs and ratio of CD8 }{ }^{+} \\
\text {T/T reg } S \\
\text { Reduction in the number of MDSC and M2-like TAMs }\end{array}$ & [134] \\
\hline $\begin{array}{l}\text { Polymeric NPs (AC- } \\
\text { CS-PpIX micelle } \\
\text { and PBA-PEG-PCL } \\
(\mathrm{DOX})^{\mathrm{b} / \text { Intratu- }} \\
\text { moral and IV) }\end{array}$ & & $\begin{array}{l}\text { TLR7 agonist, Imiquimod } \\
\text { (R837) }\end{array}$ & $\begin{array}{l}\text { Breast cancer } \\
\text { and MQ } \\
\text { models }\end{array}$ & $\begin{array}{l}\text { Enhanced anti-tumor immune response } \\
\text { Enhanced expression of IL-6, TNF-a, IL-1 } \beta \text {, and IFN- } \gamma \text {, } \\
\text { and decrease in level of IL-10 expression } \\
\text { Higher tumor inhibition rate (85\%) and an improved } \\
\text { survival rate of treated mice (80\%) }\end{array}$ & [161] \\
\hline $\begin{array}{l}\text { Polymeric NPs } \\
\text { ( }(\text {-PGA/Intratu- } \\
\text { moral) }\end{array}$ & PTX & $\begin{array}{l}\text { TLR-7 agonist, Imiqui- } \\
\text { mod }\end{array}$ & $\begin{array}{l}\text { Melanoma, lung } \\
\text { cancer, and } \\
\text { cervical cancer }\end{array}$ & $\begin{array}{l}\text { Extreme prevention of tumor growth } \\
\text { Enhanced activation and proliferation of the DCs and } \\
\text { secretion of PICs and Th1 cytokines } \\
\text { Enhancement of the population of DCs and MQs in the } \\
\text { tumor-draining lymph node }\end{array}$ & [103] \\
\hline $\begin{array}{l}\text { (Lipophilic prodrugs } \\
\text { nanoassemblies/IV) }\end{array}$ & & TLR7 agonist, Imiquimod & Breast cancer & $\begin{array}{l}\text { Effective induction of apoptosis and inhibition of } \\
\text { tumor growth and angiogenesis, with no tumor } \\
\text { recurrence } \\
\text { Stimulation of DCs through collaboration of TAAs with } \\
\text { R837 leading to potent tumor-specific immune } \\
\text { response }\end{array}$ & [162] \\
\hline $\begin{array}{l}\text { Biomimetic NPs (HDL } \\
\text { nanodiscs/Intratu- } \\
\text { moral) }\end{array}$ & DTX & TLR9 agonist, CpG ODN & Colon carcinoma & $\begin{array}{l}\text { Maximum anti-tumor efficacy and minimum off-target } \\
\text { side effects } \\
\text { Significant improvement in overall survival in } \\
\text { combination-treated mice toward mice treated with } \\
\text { DTX alone }\end{array}$ & [163] \\
\hline
\end{tabular}

aGC a-galactosylceramide, ACAT-1 acetyltransferase-1, $P E$ I polyethyleneimine, $P A M A M$ poly amidoamine, $H D L$ high density lipoprotein, $\gamma$ - $P G A$ poly( $\gamma$-glutamic acid), $A C$-CS-PpIX acetylated-chondroitin sulfate-protoporphyrin IX, PBA-PEG-PCL phenylboronic acid-polyethylene glycol-polycaprolactone, DTX docetaxel

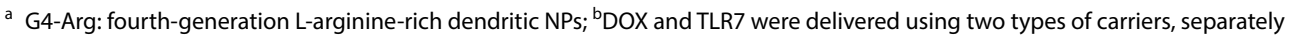

immunosuppressive TME and ameliorate the in vivo PK behaviors [121, 122]. Accordingly, several types of NPs with different physicochemical properties, including lipid NPs like liposomes, polymeric NPs, metallic or inorganic NPs like mesoporous silica nanoparticles (MSN), hydrogels, cell-derived nanovesicles like exosomes, and hybrid NPs are currently being developed as delivery systems in CIT [123-126]. Cationic lipids and polymers and hybrid NPs have been widely used as the common choice's carriers over the recent decade [127-129]. Metallic or inorganic NPs such as MSN [127, 128], graphene oxide [130], and black phosphorus [131], indicate promising roles including the latest immunogenicity, feasible potential in functionalization and synergized delivery with photothermal therapy (PTT) and photodynamic therapy (PDT) in CIT [132, 133]. Nanogel with the ability to change the core and shell structures leads to responsive functional performance for image cellular tracking and sustained delivery in CIT design [134-136].

The application and manipulation of biomimetic NPs indicate promising role in CIT such as cellular or molecular agents including high-density lipoproteins (HDL), low-density lipoproteins (LDL) [137], albumin [138], and exosome [139], therefore they can emerge predominant potential in CIT perspective. Likewise, some factors, such as biocompatibility, biodegradability, stability in favor of long-term storage, and intended release profile of payloads and delivery of them to target and administration route, should be considered when choosing a good nanocarrier [140, 141].

In studies were surveyed, different immunotherapy agents are used in NP-mediated CIT to create these consequences, which included firstly, cytokines such as IL-2, IFN- $\gamma$, IL-7, and IL-15 that are used alone or as a cocktail in various studies to facilitate the growth and activation of different immune cells (DCs, $\mathrm{CD} 4^{+}$, and $\mathrm{CD} 8^{+} \mathrm{T}$ cells, NK cells, and neutrophils). Carrier-mediated combination of chemotherapy drugs and cytokines was summarized in Table 1 . Secondly, immune-stimulating adjuvants like L-Arg, and TLR agonists including TLR4 agonist LPS and detoxified derivatives of LPS like sodium phthalate (SP-LPS) and phthalate (P-LPS) salt of parent LPS, TLR3 agonist poly I:C, TLR7 agonist imiquimod (R837), and TLR9 agonist CpG-ODN which induce an efficient antitumor response by activating MQs, inducing effector immune cells such as $\mathrm{CD}^{+} \mathrm{T}$ cell and increasing levels 
Table 3 Carrier-mediated combination of chemotherapy drugs and mAbs

\begin{tabular}{llll}
\hline $\begin{array}{l}\text { Carrier design (Structure/ } \\
\text { injection route) }\end{array}$ & $\begin{array}{l}\text { Chemotherapy } \\
\text { agent }\end{array}$ & mAbs & $\begin{array}{l}\text { Tumor type } \\
\text { of NPs in the combination }\end{array}$ \\
\hline
\end{tabular}

HDL nanodiscs (ApoA1 mimetic peptide or phospholipids ${ }^{\mathrm{a} / \mathrm{IV}}$ )

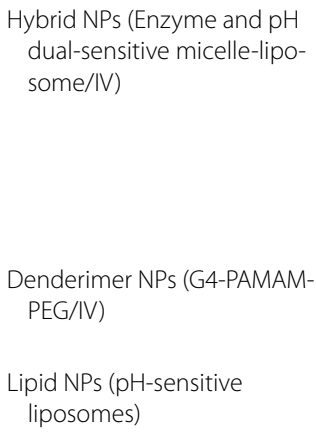

Denderimer NPs (G4-PAMAMPEG/IV)

Lipid NPs (pH-sensitive liposomes)

mAb against HER-2, Trastuzumab

PTX

PD-1/PD-L1 inhibitor HY19991

hydrogel NPs (ROS-responsive hydrogel/Peritumoral)

mAb against HER-2, Trastuzumab

Anti-PD-L1 blocking antibody
Colon adenocarcinoma

Breast cancer

Melanoma

Melanoma and breast cancer
Significant regression of colon carcinoma tumors and inhibition of tumor relapse in mice compared to monotherapy or carrier-free dual therapy Induction of long-lasting immunity and delayed tumor growth with no obvious offtarget side effects

Recruitment of the highest number of $\mathrm{CD} 8 \mathrm{a}^{+} \mathrm{T}$ cells into the TME and development of systemic antigen-specific $\mathrm{CD} \mathrm{a}^{+} \mathrm{T}$ cell responses

Remarkable cellular uptake, cytotoxic effect, and significant internalization of conjugates to the HER-2 positive cells

Synergistic therapeutic effect and enhanced selectivity compared to free drugs and PAMAM-trastuzumab, indicating that DOX dose and thus the cardiotoxicity caused by DOX could be reduced

Significant anti-cancer efficacy and high tumor inhibition and lung metastasis suppression rate

Increased T cells infiltration in tumor tissues and decrease in cancer stem cell population

Prolonged survival time of mice

Increased therapeutic efficacy of the conjugate in animal models

Significant tumor inhibition via high selectivity

(1)

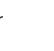

.


Table 4 Other combination of chemotherapy drugs and immunotherapy agents

Carrier design (Structure/ Chemotherapy agent Immunotherapy agents Tumor type
Injection route)
Injection route)

Lipid NPs (Pegylated liposome/IV)

DOX

Alendronate

(Hydrogel/SC)

Melittin-RADA32

( $\mathrm{pH}$-sensitive smart nanocubes/IV)

Polymeric NPs (Polymerized $\beta$-cyclodextrin/Intratumoral)

(Dual-pH-sensitive micelle system /Tail vein)
DOVA vaccine

NO

Breast cancer
Hybrid NPs (HA coated cationic albumin NPs/Tail vein)
Celastrol

IDO inhibitor, 1-methyltryp- Pancreatic cancer tophan
Female Balb/C and Sabra tumor models

Melanoma

Synergic actions and

Refs. advantages of NPs in the combination

High loading efficiency of DOX and increased stability in biological fluids

More potent activation of the inflammasome pathway leading to 40 -fold greater secretion of IL-1 $\beta$ High therapeutic efficacy due to synergy of alendronate and DOX

Considerable tumor inhibition with the activated NK cells recruitment in the tumors

Regulation of innate immune cells, direct anti-cancer and immunestimulating capabilities

Activation of DCs of draining lymph nodes, production of CTLS, and depletion of M2-like TAMs

Melanoma, MQ model and lung carcinoma

Higher anti-tumor efficacy, longer survival rates, and increased tumor inhibition ratio compared to monotherapy

Higher OVA protein production

Provoking humoral immunity after a single injection and significant humoral immunogenic memory production

Melanoma, mammary carcinoma, lymphoma and colon carcinoma

Synergistic cytotoxicity and induction of ICD on tumor cells

Activation and expansion of DCs leading to expansion of CTLS

Significant tumor accumulation, as well as tumor growth suppression

Reducing immunosuppressive MDSCs levels and increasing infiltration and anti-tumor effect of CTLs

Effective increase in expression of ApoE in tumor tissues

Suppression of TGF- $\beta$ and

IL-10 production and enhancement of the number of $\mathrm{CD}^{+}$and $\mathrm{CD}^{+} \mathrm{T}$ cells

Increase in cytotoxicity, apoptosis induction, and tumor inhibition

Downregulation of the immunosuppressive TME through upregulating $\mathrm{CD}^{+}{ }^{+} \mathrm{T}$ cells in the spleen

\section{[170]}

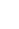


Table 4 (continued)

\begin{tabular}{|c|c|c|c|c|c|}
\hline $\begin{array}{l}\text { Carrier design (Structure/ } \\
\text { Injection route) }\end{array}$ & Chemotherapy agent & Immunotherapy agents & Tumor type & $\begin{array}{l}\text { Synergic actions and } \\
\text { advantages of NPs in the } \\
\text { combination }\end{array}$ & Refs. \\
\hline $\begin{array}{l}\text { Nanogel (Folated pH-degra- } \\
\text { dable PVA/Tail vein) }\end{array}$ & DTX & IDO1 inhibitor, NLG919 & Breast cancer & $\begin{array}{l}\text { Increased intratumoral } \\
\text { infiltration of CTLs and } \\
\text { NK cells and inhibition of } \\
\text { MDSCs infiltration } \\
\text { Regulation of IDO1-medi- } \\
\text { ated immunosuppressive } \\
\text { TME }\end{array}$ & [136] \\
\hline Lipid NPs (Liposome/IV) & DOX & IDO1 inhibitor, Indoximod & Metastatic breast cancer & $\begin{array}{l}\text { Significant increase in anti- } \\
\text { breast cancer immune } \\
\text { response } \\
\text { Remarkable tumor cell } \\
\text { elimination at the primary } \\
\text { tumor sites, as well as } \\
\text { metastatic sites } \\
\text { Activation of CTLs, depletion } \\
\text { of T }_{\text {reg }} \text {, and enhancement } \\
\text { in CD8 }{ }^{+} / \mathrm{FOXP3}^{+} \mathrm{T} \text { cell } \\
\text { ratios } \\
\text { Less toxicity in liver, heart, } \\
\text { and kidney compared to } \\
\text { free DOX }\end{array}$ & (176) \\
\hline
\end{tabular}

HA hyaluronic acid, $P V A$ polyvinyl alcohol, $L X R$ liver-X nuclear receptor, $p O V A$ plasmid ovalbumin, $N O$ nitric oxide

example, indoleamine 2,3 dioxygenase (IDO), which is overexpressed enzyme in tumor cells, enables tumors to escape immune surveillance. Likewise, 1-methyltryptophan and indoximod (as IDO inhibitors) combined with chemotherapeutic agents elicited regression of tumors significantly.

\section{Conclusion and perspective}

The understanding of immunotherapeutic strategies, including using tumor-specific mAbs, ACT, cytokines, and adjuvants in passive strategy and blockade ICP and activation of DC as active approach along with chemotherapy agents could boost CIT. Induction of immunomodulation action through ICD or eradication of immunosuppressive cells in the TME associated with utilizing some of the chemotherapy drugs, which play a CIT role alone or in combination with immunotherapy agents due to unique and effective paradigms can promote the synergistic performance in cancer CIT. Furthermore, the interplay of chemotherapy and the interface between innate and adaptive immunity, such as $\gamma \delta$ T celland NKT cell-based therapies leads to significant cancer treatment efficiency. Continued advancement in CIT, which is mediated by NPs can improve the treatment of cancers, not to mention the meaningful progress in the development of CIT not only enlighten a possible therapeutic application of anti-cancers but also apprehend a potential for harnessing in interdisciplinary research. Emerging advances in the development of NPs and discover new chemotherapeutic and immunotherapeutic agents, enable the revolution expected for more using of CIT to overcome the hurdles in developing successful new drugs and will make the perspective of CIT for better planning of long-lasting cancer treatment.

\begin{abstract}
Abbreviations
ALL: Acute lymphoblastic leukemia; ATP: Adenosine triphosphate; ACT: Adoptive cell transfer therapy; APCs: Antigen-presenting cells; CRT: Calreticulin; CIT: Chemoimmunotherapy; CAR: Chimeric antigen receptor; CpG-ODN: Cytosinephosphate-guanosine oligodeoxynucleotides; DAMPs: Damage-associated molecular patterns; DC: Dendritic cell; FDA: Food and Drug Administration; үठ: Gamma-delta; Grz B: Granzyme B; HMGB1: High mobility group box 1; ICP: Immune checkpoint; ICIs: Immune checkpoint inhibitors; ICD: Immunogenic cell death; IFN: Interferon; IL: Interleukin; LPS: Lipopolysaccharide; MQs: Macrophages; MSN: Mesoporous silica nanoparticles; mAbs: Monoclonal antibodies; MDR: Multidrug resistance; MDSCs: Myeloid-derived suppressor cells; NPs: Nanoparticles; NK: Natural killer; NLRs: NOD-like receptors; PRRs: Pathogen recognition receptors; PK: Pharmacokinetics; poly I:C: Polyinosinic-polycytidylic acid; PD-L1: Programmed cell death ligand-1; PD-1: Programmed cell death protein-1; PICs: Pro-inflammatory cytokines; STING: Stimulator of interferon genes; $T_{\text {reg }} \mathrm{s}$ : Regulatory T cells; TCR: Engineered T cell receptor; TlL: Tumor-infiltrating T lymphocyte; TLRs: Toll like receptors; TGF: Transforming growth factor; TME:Tumor microenvironment; TAMs: Tumor-associated macrophages.
\end{abstract}

\section{Acknowledgements}

This review article was written as a part of Ph.D. thesis No. 173 for Rafieh Bagherifar registered at Faculty of Pharmacy, Tabriz University of Medical Sciences, Iran. The financial aid from the Drug Applied Research Center and Faculty of Pharmacy, Tabriz University of Medical Science is greatly acknowledged

\section{Authors' contributions}

$\mathrm{RB}$ and RJ designed the work. RB, SHK, ZH, AS, and AA collected data and wrote the manuscript. AA and RB designed and regenerated the conceptual pictures. YJ, RJ and BB checked and revised the article. All authors read and approved the final manuscript. 


\section{Funding}

This research received no specific grant from any funding agency in the public, commercial, or not-for-profit sectors.

\section{Availability of data and materials}

Not applicable.

\section{Declarations}

Ethics approval and consent to participate

Not applicable.

\section{Consent for publication}

All authors give consent for the publication of manuscript in Journal of Nanobiotechnology.

\section{Competing interests}

The authors declare that they have no competing interests.

\section{Author details}

${ }^{1}$ Student Research Committee, Tabriz University of Medical Sciences, Tabriz, Iran. ${ }^{2}$ Department of Pharmaceutics, Faculty of Pharmacy, Tabriz University of Medical Sciences, Tabriz, Iran. ${ }^{3}$ Nano Drug Delivery Research Center, Kermanshah University of Medical Sciences, Kermanshah, Iran. ${ }^{4}$ Department of Immunology, Faculty of Medical Sciences, Tarbiat Modares University, Tehran, Iran. ${ }^{5}$ Department of Chemical \& Materials Engineering, The University of Alabama in Huntsville, Huntsville, AL 35899, USA. ${ }^{6}$ Cancer Research Center, Semnan University of Medical Sciences, Semnan, Iran. ${ }^{7}$ Immunology Research Center, Tabriz University of Medical Sciences, Tabriz, Iran. ${ }^{8}$ Solid Tumor Research Center, Cellular and Molecular Medicine Institute, Urmia University of Medical Sciences, Shafa St, Ershad Blvd., P.O. BoX: 1138, 57147 Urmia, Iran.

${ }^{9}$ Department of Immunology and Genetics, School of Medicine, Urmia University of Medical Sciences, Urmia, Iran. ${ }^{10}$ Biotechnology Research Center, and Faculty of Pharmacy, Tabriz University of Medical Science, 5166-15731 Tabriz, Iran.

Received: 28 January 2021 Accepted: 9 April 2021

Published online: 17 April 2021

\section{References}

1. Dai W, Wang X, Song G, Liu T, He B, Zhang H, et al. Combination antitumor therapy with targeted dual-nanomedicines. Adv Drug Deliv Rev. 2017;115:23-45.

2. Da Silva C, Rueda F, Löwik C, Ossendorp F, Cruz LJ. Combinatorial prospects of nano-targeted chemoimmunotherapy. Biomaterials. 2016;83:308-20.

3. Mahdinloo S, Kiaie SH, Amiri A, Hemmati S, Valizadeh H, Zakeri-Milani P. Efficient drug and gene delivery to liver fibrosis: rationale, recent advances, and perspectives. Acta Pharmaceutica Sinica B. 2020.

4. Pucci C, Martinelli C, Ciofani G. Innovative approaches for cancer treatment: current perspectives and new challenges. Ecancermedicalscience. 2019;13:87.

5. Cagan R, Meyer P. Rethinking cancer: current challenges and opportunities in cancer research. New York: The Company of Biologists Ltd; 2017.

6. Zugazagoitia J, Guedes C, Ponce S, Ferrer I, Molina-Pinelo S, Paz-Ares L. Current challenges in cancer treatment. Clin Ther. 2016;38(7):1551-66.

7. DeVita VT, Chu E. A history of cancer chemotherapy. Can Res. 2008;68(21):8643-53.

8. Hunger SP, Mullighan CG. Acute lymphoblastic leukemia in children. N Engl J Med. 2015;373(16):1541-52.

9. Nussbaumer S, Bonnabry P, Veuthey J-L, Fleury-Souverain S. Analysis of anticancer drugs: a review. Talanta. 2011;85(5):2265-89.

10. Luqmani Y. Mechanisms of drug resistance in cancer chemotherapy. Med Princ Pract. 2005;14(Suppl. 1):35-48.

11. Wu Q, Yang Z, Nie Y, Shi Y, Fan D. Multi-drug resistance in cancer chemotherapeutics: mechanisms and lab approaches. Cancer Lett. 2014;347(2):159-66
12. Pérez-Herrero E, Fernández-Medarde A. Advanced targeted therapies in cancer: drug nanocarriers, the future of chemotherapy. Eur J Pharm Biopharm. 2015;93:52-79.

13. Bode AM, Dong Z. Recent advances in precision oncology research. Berlin: Nature Publishing Group; 2018.

14. Li Z, Chen Y, Yang Y, Yu Y, Zhang Y, Zhu D, et al. Recent advances in nanomaterials-based chemo-photothermal combination therapy for improving cancer treatment. Front Bioeng Biotechnol. 2019;7:293.

15. Nurgali K, Jagoe RT, Abalo R. Adverse effects of cancer chemotherapy: Anything new to improve tolerance and reduce sequelae? Front Pharmacol. 2018;9:245.

16. Kruger S, Ilmer M, Kobold S, Cadilha BL, Endres S, Ormanns S, et al. Advances in cancer immunotherapy 2019-latest trends. J Exp Clin Cancer Res. 2019;38(1):1-11.

17. Murciano-Goroff YR, Warner AB, Wolchok JD. The future of cancer immunotherapy: microenvironment-targeting combinations. Cell Res. 2020;54:1-13.

18. Bonaventura P, Shekarian T, Alcazer V, Valladeau-Guilemond J, ValsesiaWittmann S, Amigorena S, et al. Cold tumors: a therapeutic challenge for immunotherapy. Front Immunol. 2019;10:168.

19. Galon J, Bruni D. Approaches to treat immune hot, altered and cold tumours with combination immunotherapies. Nat Rev Drug Discovery. 2019;18(3):197-218.

20. Oiseth SJ, Aziz MS. Cancer immunotherapy: a brief review of the history, possibilities, and challenges ahead. J Cancer Metastasis Treat. 2017;3(10):250-61.

21. Decker WK, da Silva RF, Sanabria MH, Angelo LS, Guimarães F, Burt $\mathrm{BM}$, et al. Cancer immunotherapy: historical perspective of a clinical revolution and emerging preclinical animal models. Front Immunol. 2017;8:829.

22. McCarthy EF. The toxins of William B. Coley and the treatment of bone and soft-tissue sarcomas. lowa Orthopaed J. 2006;26:154-8.

23. Old LJ, Clarke DA, Benacerraf B. Effect of Bacillus Calmette-Guerin infection on transplanted tumours in the mouse. Nature. 1959;184(Suppl 5):291-2.

24. Thomas $\mathrm{L}$, Lawrence $\mathrm{H}$. Cellular and humoral aspects of the hypersensitive states. New York: Hoeber-Harper; 1959. p. 529-32.

25. Burnet M. Cancer; a biological approach. I. The processes of control. $\mathrm{Br}$ Med J. 1957;1 (5022):779-86.

26. Finn OJ. Cancer immunology. N Engl J Med. 2008;358(25):2704-15.

27. D'Errico G, Machado HL, Sainz B. A current perspective on cancer immune therapy: step-by-step approach to constructing the magic bullet. Clin Transl Med. 2017;6(1):1-10.

28. Koury J, Lucero M, Cato C, Chang L, Geiger J, Henry D, et al. Immunotherapies: exploiting the immune system for cancer treatment. J Immunol Res. 2018;2018:78.

29. Lesterhuis WJ, Haanen JB, Punt CJ. Cancer immunotherapy-revisited. Nat Rev Drug Discov. 2011;10(8):591-600.

30. Park W, Heo Y-J, Han DK. New opportunities for nanoparticles in cancer immunotherapy. Biomater Res. 2018;22(1):1-10.

31. Jeanbart L, Swartz MA. Engineering opportunities in cancer immunotherapy. Proc Natl Acad Sci. 2015;112(47):14467-72.

32. Duan $\mathrm{Q}$, Zhang $\mathrm{H}$, Zheng J, Zhang L. turning cold into hot: firing up the tumor microenvironment. Trends Cancer. 2020;45:789.

33. Ventola CL. Cancer immunotherapy, part 3: challenges and future trends. Pharm Ther. 2017;42(8):514.

34. Emens LA. Chemoimmunotherapy. Cancer J. 2010;16(4):295.

35. Gandhi L, Rodríguez-Abreu D, Gadgeel S, Esteban E, Felip E, De Angelis $F$, et al. Pembrolizumab plus chemotherapy in metastatic non-smallcell lung cancer. N Engl J Med. 2018;378(22):2078-92.

36. Lake RA, Robinson BW. Immunotherapy and chemotherapy - a practical partnership. Nat Rev Cancer. 2005;5(5):397-405.

37. Ewens A, Luo L, Berleth E, Alderfer J, Wollman R, Hafeez BB, et al. Doxorubicin plus interleukin-2 chemoimmunotherapy against breast cancer in mice. Can Res. 2006;66(10):5419-26.

38. Heo MB, Kim S-Y, Yun WS, Lim YT. Sequential delivery of an anticancer drug and combined immunomodulatory nanoparticles for efficient chemoimmunotherapy. Int J Nanomed. 2015;10:5981.

39. Inoue H, Tani K. Multimodal immunogenic cancer cell death as a consequence of anticancer cytotoxic treatments. Cell Death Differ. 2014;21(1):39-49. 
40. Duan X, Chan C, Lin W. Nanoparticle-mediated immunogenic cell death enables and potentiates cancer immunotherapy. Angew Chem Int Ed. 2019;58(3):670-80.

41. Galluzzi L, Senovilla L, Zitvogel L, Kroemer G. The secret ally: immunostimulation by anticancer drugs. Nat Rev Drug Discov. 2012;11(3):215-33.

42. Gomez G, Hutchison R, Kruse C. Chemo-immunotherapy and chemo-adoptive immunotherapy of cancer. Cancer Treat Rev. 2001;27(6):375-402.

43. Papaioannou NE, Beniata OV, Vitsos P, Tsitsilonis O, Samara P. Harnessing the immune system to improve cancer therapy. Ann Transl Med. 2016:4:14.

44. Bertolaccini L, Olivero G. Cancer immunotherapy. A future therapeutical choice? Minerva Chirurgica. 2001;56(2):183-91.

45. Lu R-M, Hwang Y-C, Liu I-J, Lee C-C, Tsai H-Z, Li H-J, et al. Development of therapeutic antibodies for the treatment of diseases. J Biomed Sci. 2020;27(1):1-30.

46. Rosenberg SA. Cell transfer immunotherapy for metastatic solid cancer-what clinicians need to know. Nat Rev Clin Oncol. 2011:8(10):577-85.

47. Miller JS, Soignier Y, Panoskaltsis-Mortari A, McNearney SA, Yun GH, Fautsch SK, et al. Successful adoptive transfer and in vivo expansion of human haploidentical NK cells in patients with cancer. Blood. 2005;105(8):3051-7.

48. June $\mathrm{CH}, \mathrm{O}^{\prime}$ Connor RS, Kawalekar OU, Ghassemi S, Milone MC. CART cell immunotherapy for human cancer. Science. 2018;359(6382):1361-5.

49. Restifo NP, Dudley ME, Rosenberg SA. Adoptive immunotherapy for cancer: harnessing the T cell response. Nat Rev Immunol. 2012;12(4):269-81.

50. Morgan RA, Dudley ME, Wunderlich JR, Hughes MS, Yang JC, Sherry $\mathrm{RM}$, et al. Cancer regression in patients after transfer of genetically engineered lymphocytes. Science. 2006;314(5796):126-9.

51. Christian DA, Hunter CA. Particle-mediated delivery of cytokines for immunotherapy. Immunotherapy. 2012;4(4):425-41.

52. Chen DS, Mellman I. Elements of cancer immunity and the cancerimmune set point. Nature. 2017:541(7637):321-30.

53. Waldmann TA. Cytokines in cancer immunotherapy. Cold Spring Harb Perspect Biol. 2018:10(12):a028472.

54. Buchbinder El, Dutcher JP, Daniels GA, Curti BD, Patel SP, Holtan SG, et al. Therapy with high-dose Interleukin-2 (HD IL-2) in metastatic melanoma and renal cell carcinoma following PD1 or PDL1 inhibition. J Immunother Cancer. 2019:7(1):1-7.

55. Berraondo P, Sanmamed MF, Ochoa MC, Etxeberria I, Aznar MA, PérezGracia JL, et al. Cytokines in clinical cancer immunotherapy. Br J Cancer. 2019;120(1):6-15.

56. Aziz N, Detels R, Quint JJ, Li Q, Gjertson D, Butch AW. Stability of cytokines, chemokines and soluble activation markers in unprocessed blood stored under different conditions. Cytokine. 2016;84:17-24.

57. Awate $S$, Babiuk LAB, Mutwiri G. Mechanisms of action of adjuvants. Front Immunol. 2013;4:114.

58. Li K, Qu S, Chen X, Wu Q, Shi M. Promising targets for cancer immunotherapy: TLRS, RLRs, and STING-mediated innate immune pathways. Int J Mol Sci. 2017:18(2):404

59. Hanson MC, Crespo MP, Abraham W, Moynihan KD, Szeto GL, Chen SH, et al. Nanoparticulate STING agonists are potent lymph node-targeted vaccine adjuvants. J Clin Investig. 2015;125(6):2532-46.

60. Chodon T, Koya RC, Odunsi K. Active immunotherapy of cancer. Immunol Invest. 2015;44(8):817-36.

61. Bader JE, Voss K, Rathmell JC. Targeting metabolism to improve the tumor microenvironment for cancer immunotherapy. Mol Cell. 2020;78(6):1019-33

62. Hassannia H, Ghasemi Chaleshtari M, Atyabi F, Nosouhian M, Masjedi A, Hojjat-Farsangi M, et al. Blockage of immune checkpoint molecules increases T-cell priming potential of dendritic cell vaccine. Immunology. 2020;159(1):75-87.

63. Gao M, Lin M, Moffitt RA, Salazar MA, Park J, Vacirca J, et al. Direct therapeutic targeting of immune checkpoint PD-1 in pancreatic cancer. $\mathrm{Br} J$ Cancer. 2019;120(1):88-96.

64. Hargadon KM, Johnson CE, Williams CJ. Immune checkpoint blockade therapy for cancer: an overview of FDA-approved immune checkpoint inhibitors. Int Immunopharmacol. 2018;62:29-39.
65. Wu Y, Chen W, Xu ZP, Gu W. PD-L1 distribution and perspective for cancer immunotherapy-blockade, knockdown, or inhibition. Front Immunol. 2019:10:2022.

66. Zhang W, Shi L, Zhao Z, Du P, Ye X, Li D, et al. Disruption of CTLA-4 expression on peripheral blood CD8 $+\mathrm{T}$ cell enhances antitumor efficacy in bladder cancer. Cancer Chemother Pharmacol. 2019:83(5):911-20

67. Kiaie SH, Sanaei MJ, Heshmati M, Asadzadeh Z, Azimi I, Hadidi S, et al. Immune checkpoints in targeted-immunotherapy of pancreatic cancer: New hope for clinical development. Acta Pharmaceutica Sinica B. 2020.

68. Jafari S, Molavi O, Kahroba H, Hejazi MS, Maleki-Dizaji N, Barghi S, et al. Clinical application of immune checkpoints in targeted immunotherapy of prostate cancer. Cell Mol Life Sci. 2020;22:1-18.

69. Stühler V, Maas JM, Rausch S, Stenzl A, Bedke J. Immune checkpoint inhibition for the treatment of renal cell carcinoma. Expert Opin Biol Ther. 2020;20(1):83-94.

70. Queirolo P, Boutros A, Tanda E, Spagnolo F, Quaglino P. Immune-checkpoint inhibitors for the treatment of metastatic melanoma: a model of cancer immunotherapy. Seminars in cancer biology. New York: Elsevier; 2019.

71. Huang Z, Su W, Lu T, Wang Y, Dong Y, Qin Y, et al. First-line immunecheckpoint inhibitors in non-small cell lung cancer: current landscape and future progress. Front Pharmacol. 2020;11:1591.

72. Sioud M. Unleashing the therapeutic potential of dendritic and T cell therapies using RNA interference. Methods Mol Biol. 2020;2115:259-80.

73. Jafari S, Molavi O, Kahroba H, Hejazi MS, Maleki-Dizaji N, Barghi S, et al. Clinical application of immune checkpoints in targeted immunotherapy of prostate cancer. Cellular and molecular life sciences: CMLS; 2020.

74. Luo Q, Zhang L, Luo C, Jiang M. Emerging strategies in cancer therapy combining chemotherapy with immunotherapy. Cancer Lett. 2019:454:191-203.

75. Apetoh L, Ladoire S, Coukos G, Ghiringhelli F. Combining immunotherapy and anticancer agents: the right path to achieve cancer cure? Ann Oncol. 2015;26(9):1813-23.

76. Kim J, Manspeaker MP, Thomas SN. Augmenting the synergies of chemotherapy and immunotherapy through drug delivery. Acta Biomater. 2019;88:1-14.

77. Kroemer G, Galluzzi L, Kepp O, Zitvogel L. Immunogenic cell death in cancer therapy. Annu Rev Immunol. 2013;31:51-72.

78. Galluzzi L, Buqué A, Kepp O, Zitvogel L, Kroemer G. Immunogenic cell death in cancer and infectious disease. Nat Rev Immunol. 2017:17(2):97-111.

79. Ghiringhelli F, Apetoh L, Tesniere A, Aymeric L, Ma Y, Ortiz C, et al. Activation of the NLRP3 inflammasome in dendritic cells induces IL-1 beta-dependent adaptive immunity against tumors. Nat Med. 2009;15(10):1170-8

80. Vandenabeele P, Vandecasteele K, Bachert C, Krysko O, Krysko DV. Immunogenic apoptotic cell death and anticancer immunity. Adv Exp Med Biol. 2016:930:133-49.

81. Cook AM, Lesterhuis WJ, Nowak AK, Lake RA. Chemotherapy and immunotherapy: mapping the road ahead. Curr Opin Immunol. 2016:39:23-9.

82. Munn DH, Sharma MD, Johnson TS, Rodriguez P. IDO, PTEN-expressing Tregs and control of antigen-presentation in the murine tumor microenvironment. Cancer Immunol Immunother. 2017;66(8):1049-58.

83. Fujimura T, Kambayashi Y, Fujisawa Y, Hidaka T, Aiba S. Tumor-associated macrophages: therapeutic targets for skin cancer. Front Oncol. 2018;8:3.

84. Gonda K, Shibata M, Ohtake T, Matsumoto Y, Tachibana K, Abe N, et al. Myeloid-derived suppressor cells are increased and correlated with type 2 immune responses, malnutrition, inflammation, and poor prognosis in patients with breast cancer. Oncol Lett. 2017:14(2):1766-74.

85. Chang CL, Hsu YT, Wu CC, Lai YZ, Wang C, Yang YC, et al. Dose-dense chemotherapy improves mechanisms of antitumor immune response. Cancer Res. 2013;73(1):119-27.

86. Ramakrishnan R, Assudani D, Nagaraj S, Hunter T, Cho HI, Antonia S, et al. Chemotherapy enhances tumor cell susceptibility to CTLmediated killing during cancer immunotherapy in mice. J Clin Investig. 2010;120(4):1111-24

87. Gogoi D, Chiplunkar SV. Targeting gamma delta T cells for cancer immunotherapy: bench to bedside. Indian J Med Res. 2013;138(5):755-61.

88. Rabb H. The T cell as a bridge between innate and adaptive immune systems: implications for the kidney. Kidney Int. 2002;61 (6):1935-46. 
89. Nussbaumer $\mathrm{O}$, Koslowski M. The emerging role of $\gamma \delta \mathrm{T}$ cells in cancer immunotherapy. Immuno-Oncol Technol. 2019;1:3-10.

90. Zou C, Zhao P, Xiao Z, Han X, Fu F, Fu L. үठ T cells in cancer immunotherapy. Oncotarget. 2017;8(5):8900.

91. Krijgsman D, Hokland M, Kuppen PJ. The role of natural killer T cells in cancer-a phenotypical and functional approach. Front Immunol. 2018;9:367.

92. Nair S, Dhodapkar MV. Natural killer T cells in cancer immunotherapy. Front Immunol. 2017:8:1178.

93. Mattarollo SR, Kenna T, Nieda M, Nicol AJ. Chemotherapy pretreatment sensitizes solid tumor-derived cell lines to $V$ alpha 24+ NKT cell-mediated cytotoxicity. Int J Cancer. 2006;1 19(7):1630-7.

94. Shmeeda H, Amitay Y, Gorin J, Tzemach D, Mak L, Stern ST, et al. Coencapsulation of alendronate and doxorubicin in pegylated liposomes: a novel formulation for chemoimmunotherapy of cancer. J Drug Target. 2016;24(9):878-89.

95. Neville-Webbe HL, Evans CA, Coleman RE, Holen I. Mechanisms of the synergistic interaction between the bisphosphonate zoledronic acid and the chemotherapy agent paclitaxel in breast cancer cells in vitro. Tumour Biol. 2006;27(2):92-103.

96. Ullén A, Lennartsson L, Harmenberg U, Hjelm-Eriksson M, Kälkner KM, Lennernäs $B$, et al. Additive/synergistic antitumoral effects on prostate cancer cells in vitro following treatment with a combination of docetaxel and zoledronic acid. Acta Oncol. 2005;44(6):644-50.

97. Xie YH, Chen YX, Fang JY. Comprehensive review of targeted therapy for colorectal cancer. Signal Transduct Target Ther. 2020;5(1):22.

98. Middleton G, Silcocks P, Cox T, Valle J, Wadsley J, Propper D, et al. Gemcitabine and capecitabine with or without telomerase peptide vaccine GV1001 in patients with locally advanced or metastatic pancreatic cancer (TeloVac): an open-label, randomised, phase 3 trial. Lancet Oncol. 2014;15(8):829-40.

99. Nars MS, Kaneno R. Immunomodulatory effects of low dose chemotherapy and perspectives of its combination with immunotherapy. Int J Cancer. 2013;132(11):2471-8.

100. Zheng M, Yue C, Ma Y, Gong P, Zhao P, Zheng C, et al. Single-step assembly of DOX/ICG loaded lipid-polymer nanoparticles for highly effective chemo-photothermal combination therapy. ACS Nano. 2013;7(3):2056-67.

101. Bayat Mokhtari R, Homayouni TS, Baluch N, Morgatskaya E, Kumar S, Das B, et al. Combination therapy in combating cancer. Oncotarget. 2017:8(23):38022-43.

102. Chen Y, Xia R, Huang Y, Zhao W, Li J, Zhang X, et al. An immunostimulatory dual-functional nanocarrier that improves cancer immunochemotherapy. Nat Commun. 2016;7:13443.

103. Seth A, Heo MB, Lim YT. Poly ( $\gamma$-glutamic acid) based combination of water-insoluble paclitaxel and TLR7 agonist for chemo-immunotherapy. Biomaterials. 2014;35(27):7992-8001.

104. Lohmueller J, Finn OJ. Current modalities in cancer immunotherapy: immunomodulatory antibodies, CARs and vaccines. Pharmacol Ther. 2017;178:31-47.

105. Thallinger C, Füreder T, Preusser M, Heller G, Müllauer L, Höller C, et al. Review of cancer treatment with immune checkpoint inhibitors. Wien Klin Wochenschr. 2018;130(3-4):85-91.

106. Zhou Y, Chen C, Zhang X, Fu S, Xue C, Ma Y, et al. Immune-checkpoint inhibitor plus chemotherapy versus conventional chemotherapy for first-line treatment in advanced non-small cell lung carcinoma: a systematic review and meta-analysis. J Immunother Cancer. 2018;6(1):155.

107. Langer CJ, Gadgeel SM, Borghaei H, Papadimitrakopoulou VA, Patnaik A, Powell SF, et al. Carboplatin and pemetrexed with or without pembrolizumab for advanced, non-squamous non-small-cell lung cancer: a randomised, phase 2 cohort of the open-label KEYNOTE-021 study. Lancet Oncol. 2016;17(11):1497-508.

108. Gandhi L, Rodríguez-Abreu D, Gadgeel S, Esteban E, Felip E, De Angelis $F$, et al. Pembrolizumab plus chemotherapy in metastatic non-small-cell lung cancer. N Engl J Med. 2018;378(22):2078-92.

109. Vera Aguilera J, Paludo J, Bangalore A, Failing J, McWilliams RR, Kottschade LA, et al. Chemoimmunotherapy combination after PD-1 inhibitor failure to improve clinical outcomes in metastatic melanoma patients. Am Soc Clin Oncol. 2018;12:78.
110. Li F, Zhao Y, Wei L, Li S, Liu J. Tumor-infiltrating Treg, MDSC, and IDO expression associated with outcomes of neoadjuvant chemotherapy of breast cancer. Cancer Biol Ther. 2018;19(8):695-705.

111. Ghiringhelli F, Menard C, Puig PE, Ladoire S, Roux S, Martin F, et al. Metronomic cyclophosphamide regimen selectively depletes CD4+ CD25+ regulatory T cells and restores T and NK effector functions in end stage cancer patients. Cancer Immunol Immunother. 2007;56(5):641-8.

112. Michels T, Shurin GV, Naiditch H, Sevko A, Umansky V, Shurin MR. Paclitaxel promotes differentiation of myeloid-derived suppressor cells into dendritic cells in vitro in a TLR4-independent manner. J Immunotoxicol. 2012;9(3):292-300.

113. Ghiringhelli F, Larmonier N, Schmitt E, Parcellier A, Cathelin D, Garrido C, et al. CD4+ CD25+ regulatory T cells suppress tumor immunity but are sensitive to cyclophosphamide which allows immunotherapy of established tumors to be curative. Eur J Immunol. 2004;34(2):336-44.

114. Chalmin F, Ladoire S, Mignot G, Vincent J, Bruchard M, Remy-Martin J-P, et al. Membrane-associated Hsp72 from tumor-derived exosomes mediates STAT3-dependent immunosuppressive function of mouse and human myeloid-derived suppressor cells. J Clin Investig. 2010;120(2):457-71.

115. Locy H, De Mey S, De Mey W, De Ridder M, Thielemans K, Maenhout SK. Immunomodulation of the tumor microenvironment: turn foe into friend. Front Immunol. 2018:9:2909.

116. Kersten K, Salvagno C, de Visser KE. Exploiting the immunomodulatory properties of chemotherapeutic drugs to improve the success of cancer immunotherapy. Front Immunol. 2015;6:516.

117. Obeid M, Tesniere A, Ghiringhelli F, Fimia G, Apetoh L, Perfettini J, Ciccosanti F, Piacentini M, Zitvogel L, Kroemer G, et al. Calreticulin exposure dictates the immunogenicity of cancer cell death. Nat Med. 2007:13:54-61.

118. Bezu L, Gomes-da-Silva LC, Dewitte H, Breckpot K, Fucikova J, Spisek R, et al. Combinatorial strategies for the induction of immunogenic cell death. Front Immunol. 2015;6:187.

119. Akao T, Kimura T, Hirofuji Y, Matsunaga K, Imayoshi R, Nagao J, et al. A poly ( $\gamma$-glutamic acid)-amphiphile complex as a novel nanovehicle for drug delivery system. J Drug Target. 2010;18(7):550-6.

120. Kong M, Tang J, Qiao Q, Wu T, Qi Y, Tan S, et al. Biodegradable hollow mesoporous silica nanoparticles for regulating tumor microenvironment and enhancing antitumor efficiency. Theranostics. 2017;7(13):3276.

121. Le Q-V, Suh J, Oh Y-K. Nanomaterial-based modulation of tumor microenvironments for enhancing chemo/immunotherapy. AAPS J. 2019;21(4):64

122. Hu CMJ, Aryal S, Zhang L. Nanoparticle-assisted combination therapies for effective cancer treatment. Ther Deliv. 2010;1(2):323-34.

123. He C, Tang Z, Tian H, Chen X. Co-delivery of chemotherapeutics and proteins for synergistic therapy. Adv Drug Deliv Rev. 2016;98:64-76.

124. Guo J, Yu Z, Sun D, Zou Y, Liu Y, Huang L. Two nanoformulations induce reactive oxygen species and immunogenetic cell death for synergistic chemo-immunotherapy eradicating colorectal cancer and hepatocellular carcinoma. Mol Cancer. 2021;20(1):1-17.

125. Aslan C, Kiaie SH, Zolbanin NM, Lotfinejad P, Ramezani R, Kashanchi F, et al. Exosomes for mRNA delivery: a novel biotherapeutic strategy with hurdles and hope. BMC Biotechnol. 2021;21(1):1-12.

126. Kiaie S, Karami C, Khodadadian A, Taher M, Soltanian S. A facile method for detection of $\mathrm{N}$-acetylcysteine and $\mathrm{L}$-cysteine with silver nanoparticle in aqueous environments. J Bioequiv Availab. 2016:8:197-203.

127. Qian G, Wang $X$, Li X, Ito A, Sogo Y, Ye J. An immuno-potentiating vehicle made of mesoporous silica-zinc oxide micro-rosettes with enhanced doxorubicin loading for combined chemoimmunotherapy. Chem Commun. 2019;55(7):961-4.

128. Gao Y, Gao D, Shen J, Wang Q. A review of mesoporous silica nanoparticle delivery systems in chemo-based combination cancer therapies. Front Chem. 2020;8:1086.

129. Mukherjee A, Waters AK, Kalyan P, Achrol AS, Kesari S, Yenugonda VM. Lipid-polymer hybrid nanoparticles as a next-generation drug delivery platform: state of the art, emerging technologies, and perspectives. Int J Nanomed. 2019;14:1937. 
130. Jiang T, Sun W, Zhu Q, Burns NA, Khan SA, Mo R, et al. Furin-mediated sequential delivery of anticancer cytokine and small-molecule drug shuttled by graphene. Adv Mater. 2015;27(6):1021-8.

131. Ou W, Byeon JH, Thapa RK, Ku SK, Yong CS, Kim JO. Plug-and-Play nanorization of coarse black phosphorus for targeted chemo-photoimmunotherapy of colorectal cancer. ACS Nano. 2018;12(10):10061-74.

132. Wang J, Fang L, Li P, Ma L, Na W, Cheng C, et al. Inorganic nanozyme with combined self-oxygenation/degradable capabilities for sensitized cancer immunochemotherapy. Nano-Micro Letters. 2019;11(1):1-18.

133. Chen L, Zhou L, Wang C, Han Y, Lu Y, Liu J, et al. Tumor-targeted drug and $\mathrm{CpG}$ delivery system for phototherapy and docetaxel-enhanced immunotherapy with polarization toward M1-type macrophages on triple negative breast cancers. Adv Mater. 2019;31(52):1904997.

134. Dong X, Yang A, Bai Y, Kong D, Lv F. Dual fluorescence imaging-guided programmed delivery of doxorubicin and $\mathrm{CpG}$ nanoparticles to modulate tumor microenvironment for effective chemo-immunotherapy. Biomaterials. 2020;230:119659

135. Nishikawa M, Mizuno Y, Mohri K, Matsuoka N, Rattanakiat S, Takahashi $Y$, et al. Biodegradable CpG DNA hydrogels for sustained delivery of doxorubicin and immunostimulatory signals in tumor-bearing mice. Biomaterials. 2011;32(2):488-94.

136. Qiao H, Chen X, Chen E, Zhang J, Huang D, Yang D, et al. Folated pHdegradable nanogels for the simultaneous delivery of docetaxel and an IDO1-inhibitor in enhancing cancer chemo-immunotherapy. Biomater Sci. 2019;7(7):2749-58

137. Kadiyala P, Li D, Nuñez FM, Altshuler D, Doherty R, Kuai R, et al. Highdensity lipoprotein-mimicking nanodiscs for chemo-immunotherapy against glioblastoma multiforme. ACS Nano. 2019;13(2):1365-84.

138. Zhao P, Wang Y, Kang X, Wu A, Yin W, Tang Y, et al. Dual-targeting biomimetic delivery for anti-glioma activity via remodeling the tumor microenvironment and directing macrophage-mediated immunotherapy. Chem Sci. 2018;9(10):2674-89.

139. Lv Q, Cheng L, Lu Y, Zhang X, Wang Y, Deng J, et al. Thermosensitive exosome-liposome hybrid nanoparticle-mediated chemoimmunotherapy for improved treatment of metastatic peritoneal cancer. Adv Sci. 2020;7(18):2000515.

140. Kiaie SH, Mojarad-Jabali S, Khaleseh F, Allahyari S, Taheri E, Zakeri-Milani $\mathrm{P}$, et al. Axial pharmaceutical properties of liposome in cancer therapy: recent advances and perspectives. Int J Pharm. 2020;119:269.

141. Mundargi RC, Babu VR, Rangaswamy V, Patel P, Aminabhavi TM. Nano/ micro technologies for delivering macromolecular therapeutics using poly (D, L-lactide-co-glycolide) and its derivatives. J Control Release. 2008;125(3):193-209.

142. Wu J, Tang C, Yin C. Co-delivery of doxorubicin and interleukin-2 via chitosan based nanoparticles for enhanced antitumor efficacy. Acta Biomater. 2017:47:81-90.

143. Yin Y, Hu Q, Xu C, Qiao Q, Qin X, Song Q, et al. Co-delivery of doxorubicin and interferon- $\gamma$ by thermosensitive nanoparticles for cancer immunochemotherapy. Mol Pharm. 2018;15(9):4161-72.

144. Lv Q, He C, Quan F, Yu S, Chen X. DOX/IL-2/IFN- $\gamma$ co-loaded thermo-sensitive polypeptide hydrogel for efficient melanoma treatment. Bioactive materials. 2018;3(1):118-28.

145. Wu T, Qiao Q, Qin X, Zhang D, Zhang Z. Immunostimulatory cytokine and doxorubicin co-loaded nanovesicles for cancer immunochemotherapy. Nanomedicine. 2019;18:66-77.

146. Wu X, He C, Wu Y, Chen X, Cheng J. Nanogel-incorporated physical and chemical hybrid gels for highly effective chemo-protein combination therapy. Adv Func Mater. 2015;25(43):6744-55.

147. Zhao Y, Song Q, Yin Y, Wu T, Hu X, Gao X, et al. Immunochemotherapy mediated by thermosponge nanoparticles for synergistic anti-tumor effects. J Control Release. 2018;269:322-36.

148. Song Q, Yin Y, Shang L, Wu T, Zhang D, Kong M, et al. Tumor microenvironment responsive nanogel for the combinatorial antitumor effect of chemotherapy and immunotherapy. Nano Lett. 2017;17(10):6366-75.

149. Hu Q, Shang L, Wang M, Tu K, Hu M, Yu Y, et al. Co-Delivery of Paclitaxel and Interleukin-12 Regulating Tumor Microenvironment for Cancer Immunochemotherapy. Adv Healthcare Mater. 2020;9(10):1901858.

150. Wu X, Wu Y, Ye H, Yu S, He C, Chen X. Interleukin-15 and cisplatin coencapsulated thermosensitive polypeptide hydrogels for combined immuno-chemotherapy. J Control Release. 2017;255:81-93.
151. Jiang L, Ding Y, Xue X, Zhou S, Li C, Zhang X, et al. Entrapping multifunctional dendritic nanoparticles into a hydrogel for local therapeutic delivery and synergetic immunochemotherapy. Nano Res. 2018;11(11):6062-73.

152. Li M, Yang Y, Xu C, Wei J, Liu Y, Cun X, et al. Tumor-targeted chemoimmunotherapy with immune-checkpoint blockade for enhanced antimelanoma efficacy. AAPS J. 2019;21(2):18.

153. Li M, Yang Y, Wei J, Cun X, Lu Z, Qiu Y, et al. Enhanced chemo-immunotherapy against melanoma by inhibition of cholesterol esterification in CD8+ T cells. Nanomedicine. 2018;14(8):2541-50.

154. Roy A, Singh MS, Upadhyay P, Bhaskar S. Nanoparticle mediated codelivery of paclitaxel and a TLR-4 agonist results in tumor regression and enhanced immune response in the tumor microenvironment of a mouse model. Int J Pharm. 2013;445(1-2):171-80.

155. Roy A, Singh MS, Upadhyay P, Bhaskar S. Combined chemo-immunotherapy as a prospective strategy to combat cancer: a nanoparticle based approach. Mol Pharm. 2010;7(5):1778-88.

156. Roy A, Chandra S, Mamilapally S, Upadhyay P, Bhaskar S. Anticancer and immunostimulatory activity by conjugate of paclitaxel and non-toxic derivative of LPS for combined chemo-immunotherapy. Pharm Res. 2012;29(8):2294-309.

157. Pawar VK, Singh Y, Sharma K, Shrivastav A, Sharma A, Singh A, et al. Doxorubicin hydrochloride loaded zymosan-polyethylenimine biopolymeric nanoparticles for dual 'chemoimmunotherapeutic'intervention in breast cancer. Pharm Res. 2017;34(9):1857-71.

158. Da Silva CG, Camps MG, Li TM, Zerrillo L, Löwik CW, Ossendorp F, et al. Effective chemoimmunotherapy by co-delivery of doxorubicin and immune adjuvants in biodegradable nanoparticles. Theranostics. 2019:9(22):6485.

159. Lee I-H, An S, Yu MK, Kwon H-K, Im S-H, Jon S. Targeted chemoimmunotherapy using drug-loaded aptamer-dendrimer bioconjugates. Control Release. 2011;155(3):435-41.

160. Han Y, Ding B, Zhao Z, Zhang H, Sun B, Zhao Y, et al. Immune lipoprotein nanostructures inspired relay drug delivery for amplifying antitumor efficiency. Biomaterials. 2018;185:205-18.

161. Wei X, Liu L, Li X, Wang Y, Guo X, Zhao J, et al. Selectively targeting tumor-associated macrophages and tumor cells with polymeric micelles for enhanced cancer chemo-immunotherapy. J Control Release. 2019;313:42-53.

162. Kang T, Li Y, Wang Y, Zhu J, Yang L, Huang Y, et al. Modular engineering of targeted dual-drug nanoassemblies for cancer chemoimmunotherapy. ACS Appl Mater Interfaces. 2019;11(40):36371-82.

163. Scheetz LM, Yu M, Li D, Castro MG, Moon JJ, Schwendeman A. Synthetic HDL nanoparticles delivering docetaxel and CpG for chemoimmunotherapy of colon adenocarcinoma. Int J Mol Sci. 2020;21(5):1777.

164. Kuai R, Yuan W, Son S, Nam J, Xu Y, Fan Y, et al. Elimination of established tumors with nanodisc-based combination chemoimmunotherapy. Sci Adv. 2018;4(4):1736.

165. Marcinkowska M, Sobierajska E, Stanczyk M, Janaszewska A, Chworos A, Klajnert-Maculewicz B. Conjugate of PAMAM dendrimer, doxorubicin and monoclonal antibody - trastuzumab: the new approach of a wellknown strategy. Polymers. 2018;10(2):187.

166. Lang T, Liu Y, Zheng Z, Ran W, Zhai Y, Yin Q, et al. Cocktail strategy based on spatio-temporally controlled nano device improves therapy of breast cancer. Adv Mater. 2019;31(5):1806202.

167. Ma P, Zhang X, Ni L, Li J, Zhang F, Wang Z, et al. Targeted delivery of polyamidoamine-paclitaxel conjugate functionalized with anti-human epidermal growth factor receptor 2 trastuzumab. Int J Nanomed. 2015;10:2173.

168. Gu Z, Wang Q, Shi Y, Huang Y, Zhang J, Zhang X, et al. Nanotechnologymediated immunochemotherapy combined with docetaxel and PD-L1 antibody increase therapeutic effects and decrease systemic toxicity. J Control Release. 2018;286:369-80.

169. Wang C, Wang J, Zhang X, Yu S, Wen D, Hu Q, et al. In situ formed reactive oxygen species-responsive scaffold with gemcitabine and checkpoint inhibitor for combination therapy. Sci TransI Med. 2018;10:429.

170. Shmeeda H, Amitay Y, Gorin J, Tzemach D, Mak L, Stern ST, et al. Coencapsulation of alendronate and doxorubicin in pegylated liposomes: a novel formulation for chemoimmunotherapy of cancer. J Drug Target. 2016:24(9):878-89. 
171. Jin H, Wan C, Zou Z, Zhao G, Zhang L, Geng Y, et al. Tumor ablation and therapeutic immunity induction by an injectable peptide hydrogel. ACS Nano. 2018;12(4):3295-310.

172. Duong HTT, Thambi T, Yin Y, Lee JE, Seo YK, Jeong JH, et al. Smart $\mathrm{pH}$-responsive nanocube-controlled delivery of DNA vaccine and chemotherapeutic drugs for chemoimmunotherapy. ACS Appl Mater Interfaces. 2019:11(14):13058-68.

173. Kim J, Sestito LF, Im S, Kim WJ, Thomas SN. Poly (cyclodextrin)-polydrug nanocomplexes as synthetic oncolytic virus for locoregional melanoma chemoimmunotherapy. Adv Func Mater. 2020;30(16):1908788.

174. Wan D, Yang Y, Liu Y, Cun X, Li M, Xu S, et al. Sequential depletion of myeloid-derived suppressor cells and tumor cells with a dual-pHsensitive conjugated micelle system for cancer chemoimmunotherapy. J Control Release. 2020;317:43-56.
175. Hu Y, Chen X, Xu Y, Han X, Wang M, Gong T, et al. Hierarchical assembly of hyaluronan coated albumin nanoparticles for pancreatic cancer chemoimmunotherapy. Nanoscale. 2019;11(35):16476-87.

176. Lu J, Liu X, Liao Y-P, Wang X, Ahmed A, Jiang W, et al. Breast cancer chemo-immunotherapy through liposomal delivery of an immunogenic cell death stimulus plus interference in the IDO-1 pathway. ACS Nano. 2018;12(11):11041-61.

\section{Publisher's Note}

Springer Nature remains neutral with regard to jurisdictional claims in published maps and institutional affiliations.
Ready to submit your research? Choose BMC and benefit from:

- fast, convenient online submission

- thorough peer review by experienced researchers in your field

- rapid publication on acceptance

- support for research data, including large and complex data types

- gold Open Access which fosters wider collaboration and increased citations

- maximum visibility for your research: over 100M website views per year

At BMC, research is always in progress.

Learn more biomedcentral.com/submissions 